\title{
Synthesis of 5,12-Diazapentacenes and Their Properties
}

Rosalva C. Garcia, Matthew J. Pech, Roger Sommer, and Christopher B. Gorman*

Department of Chemistry, North Carolina State University, Box 8204, Raleigh, NC 27695, USA

*cbgorman@ncsu.edu

\section{SUPPORTING INFORMATION}

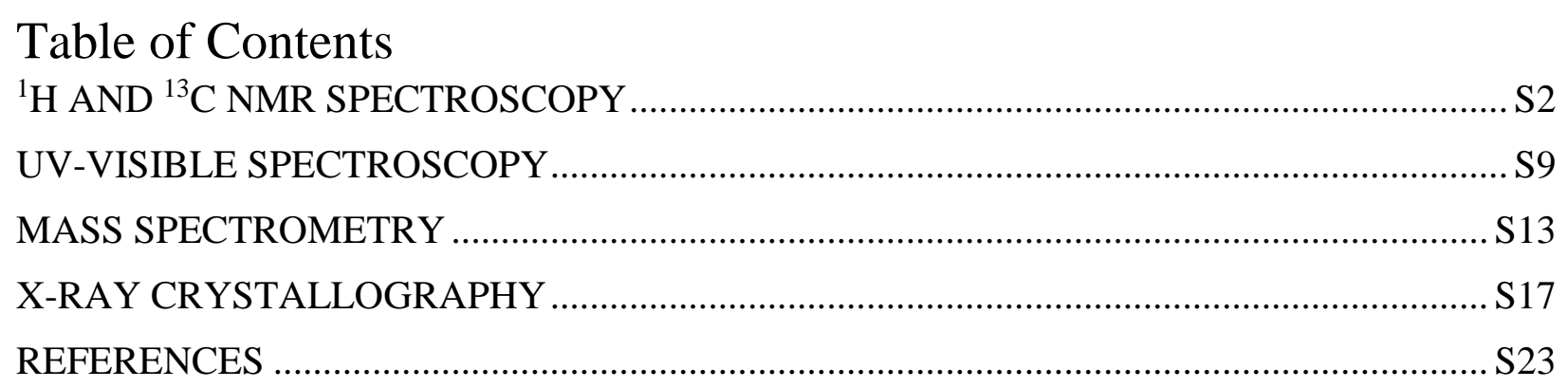


${ }^{1} \mathrm{H}$ AND ${ }^{13} \mathrm{C}$ NMR SPECTROSCOPY

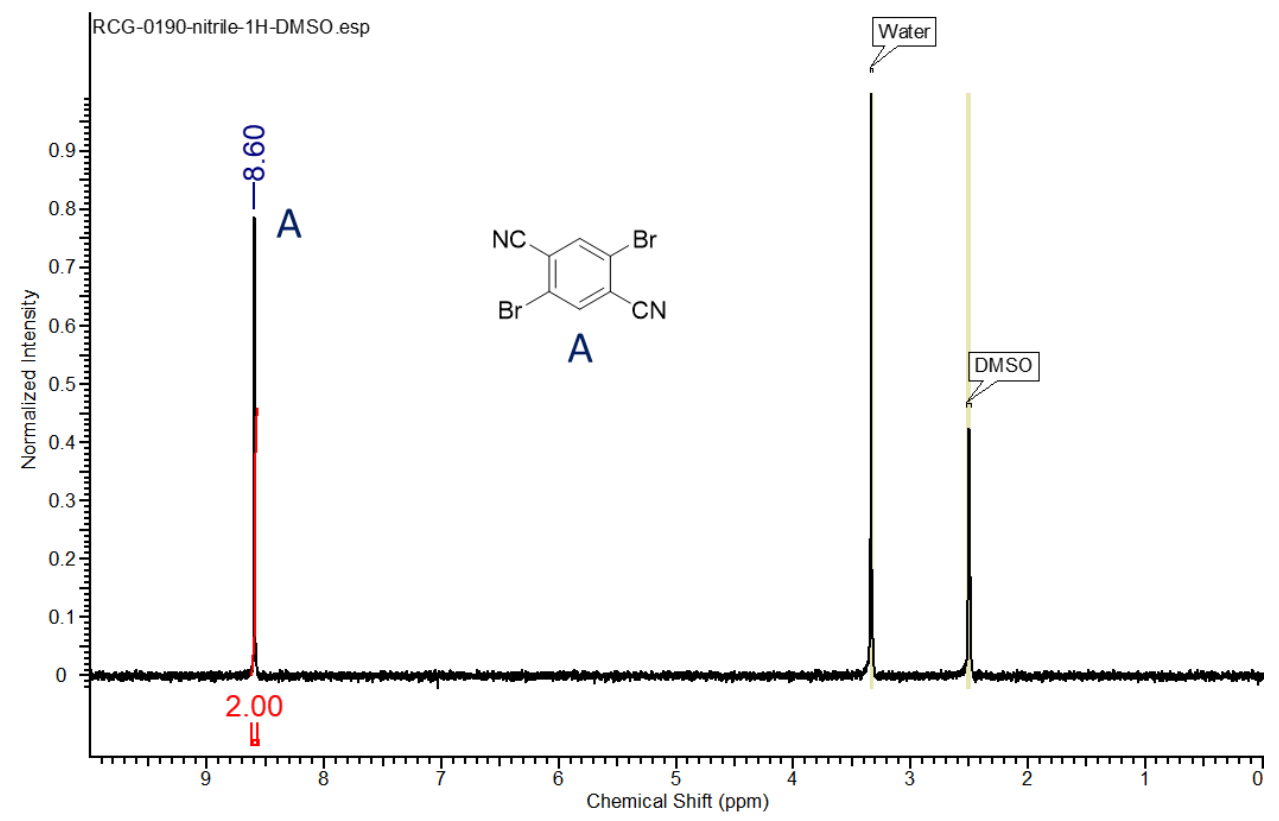

Figure S1. ${ }^{1} \mathrm{H}$ NMR spectrum $\left(400 \mathrm{MHz}, \mathrm{DMSO}-d_{6}\right)$ of $\mathbf{1}$.

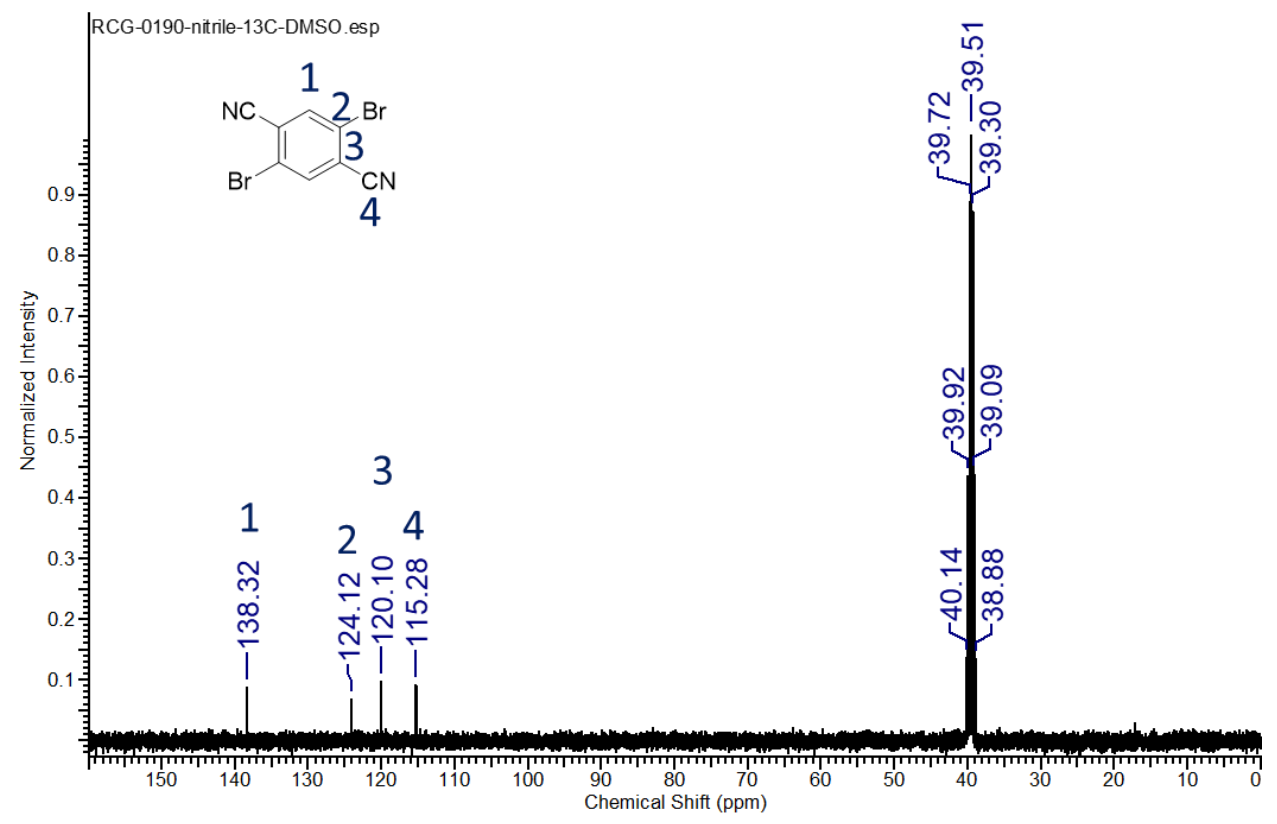

Figure S2. ${ }^{13} \mathrm{C}\{\mathrm{H}\} \mathrm{NMR}$ spectrum $\left(100 \mathrm{MHz}, \mathrm{DMSO}-d_{6}\right)$ of $\mathbf{1}$. 


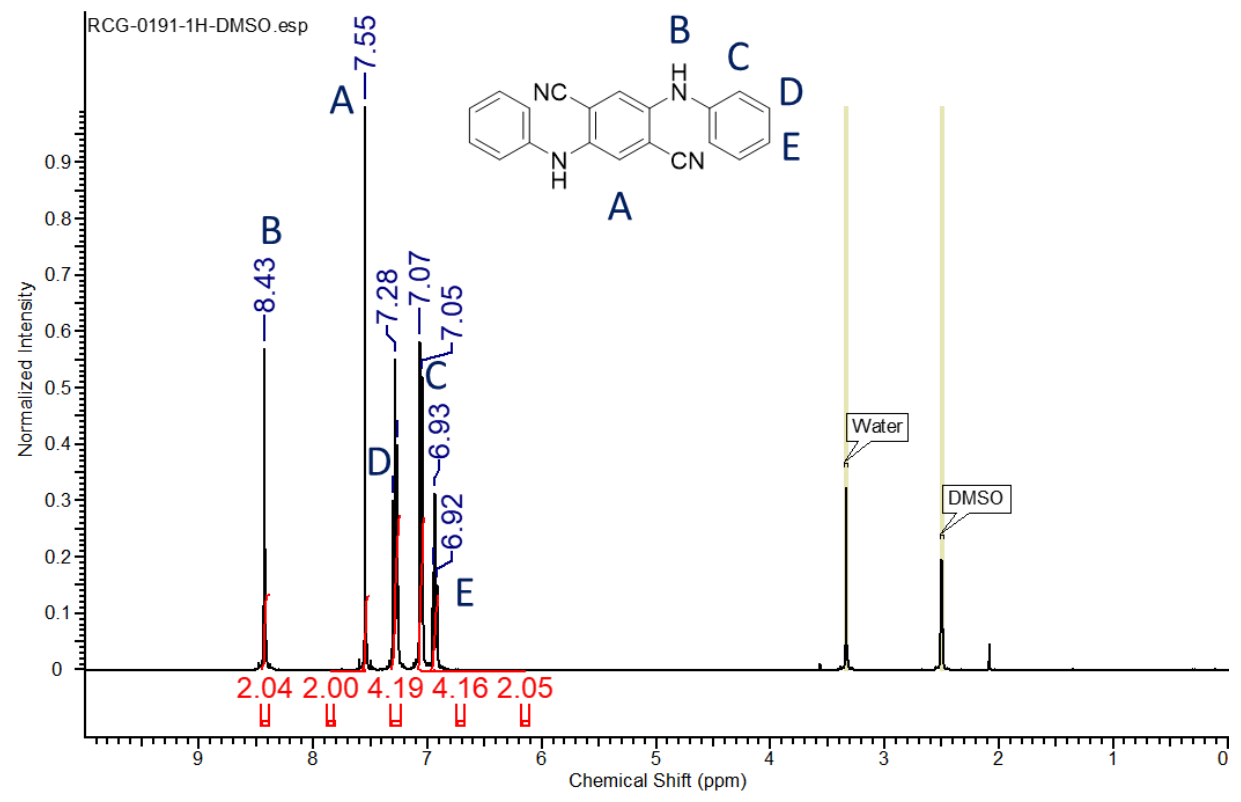

Figure S3. ${ }^{1} \mathrm{H}$ NMR spectrum $\left(400 \mathrm{MHz}, \mathrm{DMSO}-d_{6}\right)$ of $2 a$.

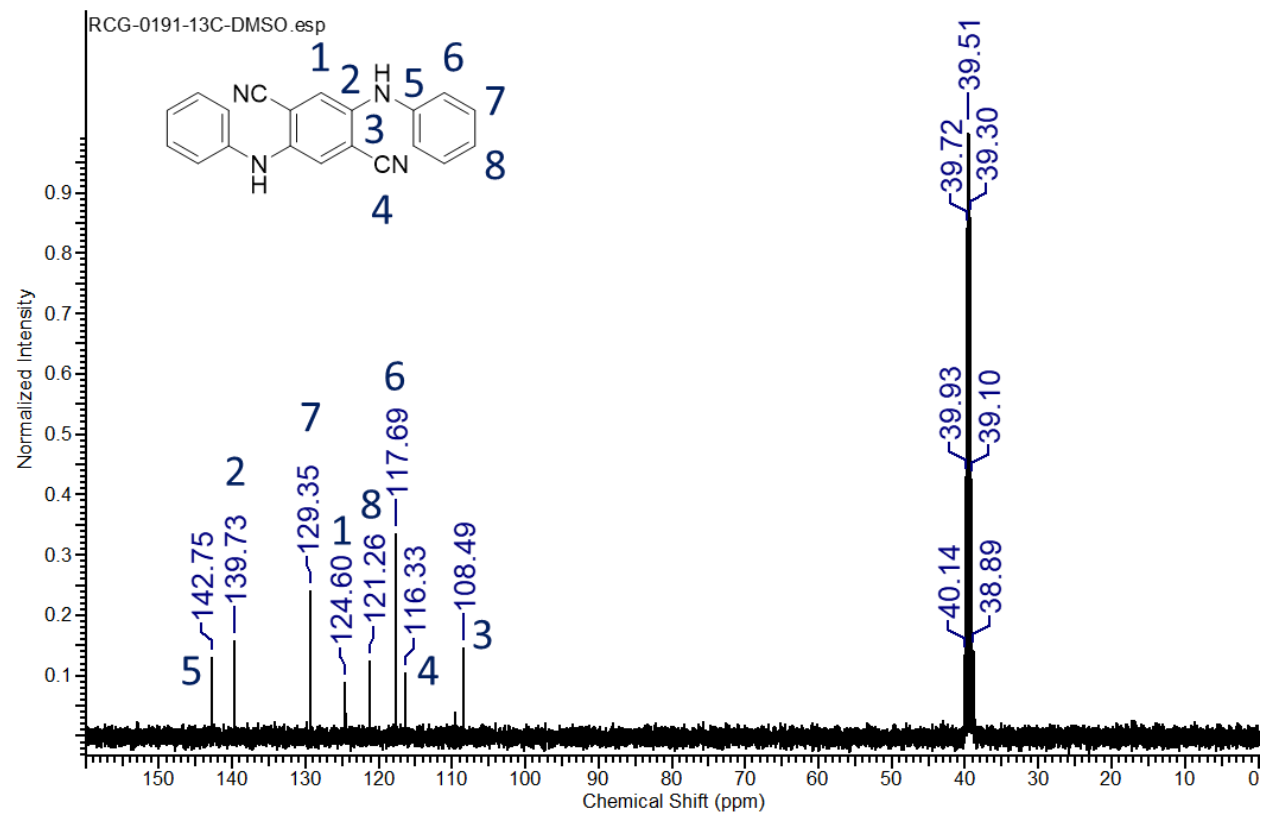

Figure S4. ${ }^{13} \mathrm{C}\{\mathrm{H}\}$ NMR spectrum $\left(100 \mathrm{MHz}, \mathrm{DMSO}-d_{6}\right)$ of $2 a$. 


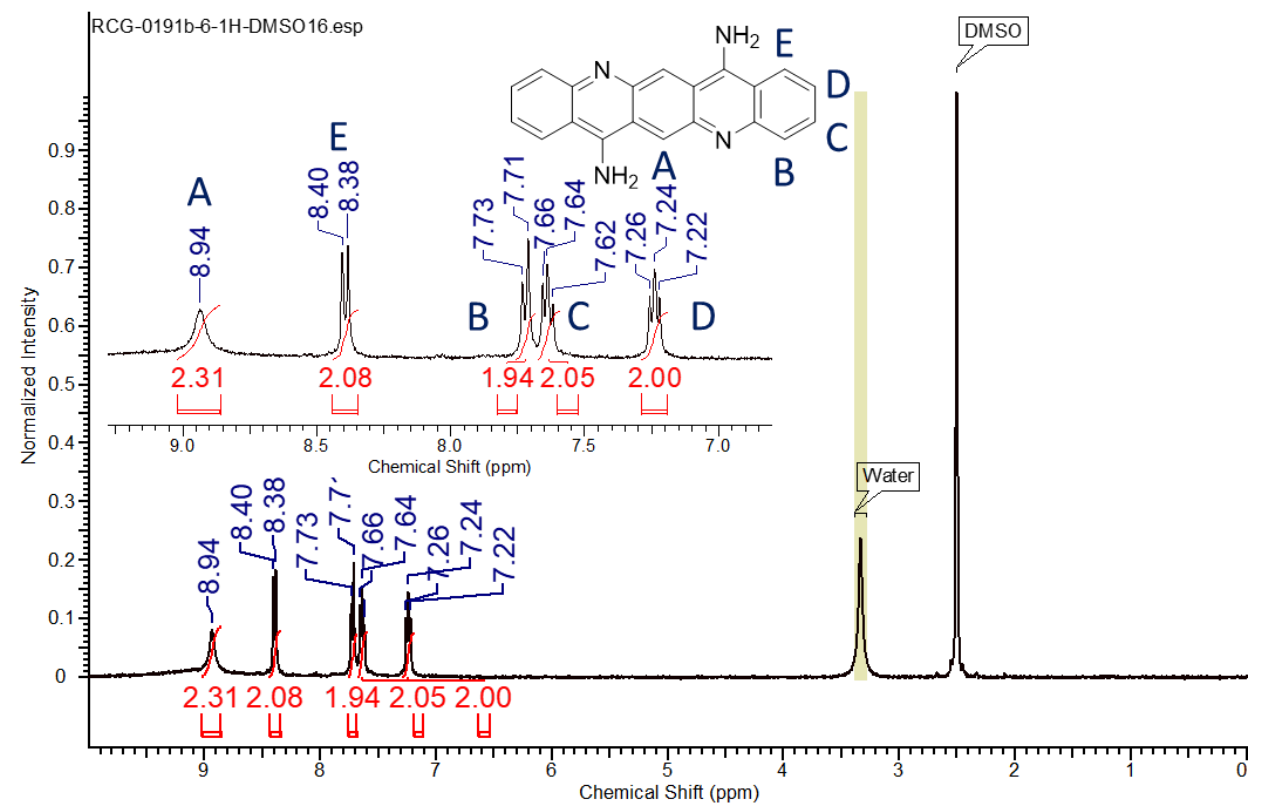

Figure S5. ${ }^{1} \mathrm{H}$ NMR spectrum of (400 MHz, DMSO-d 6 ) of $\mathbf{2 b}$.

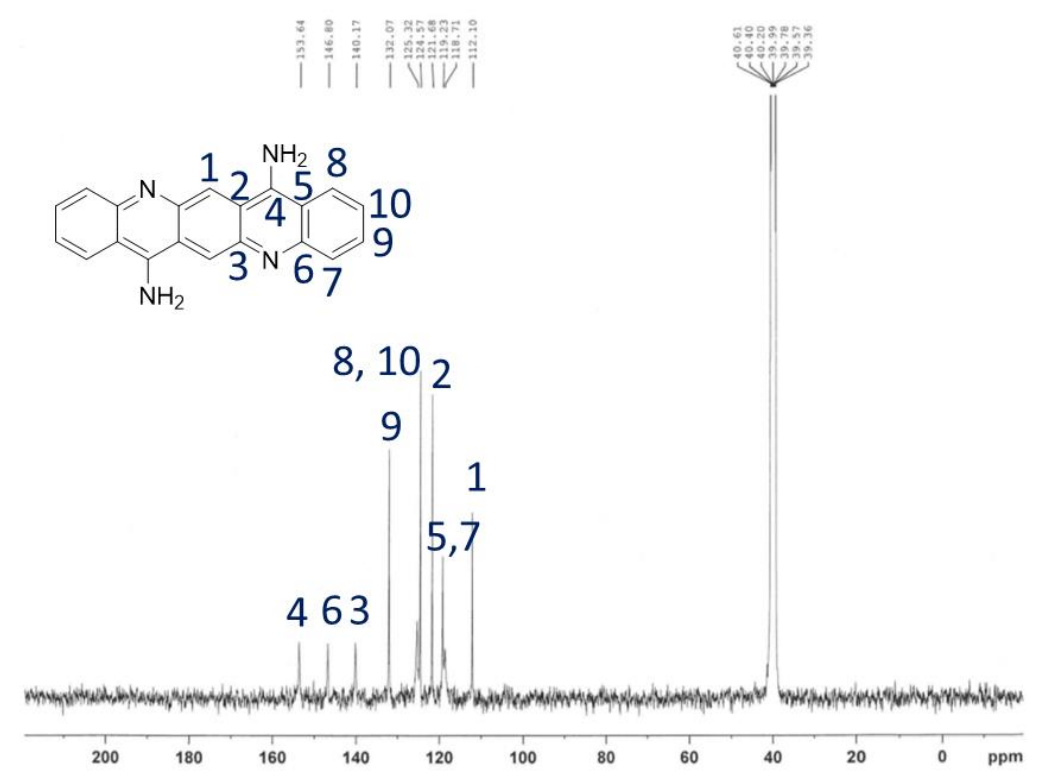

Figure S6. ${ }^{13} C\{H\} N M R$ spectrum (176 MHz, DMSO-d ${ }^{2}$ of $2 \boldsymbol{b}$. 


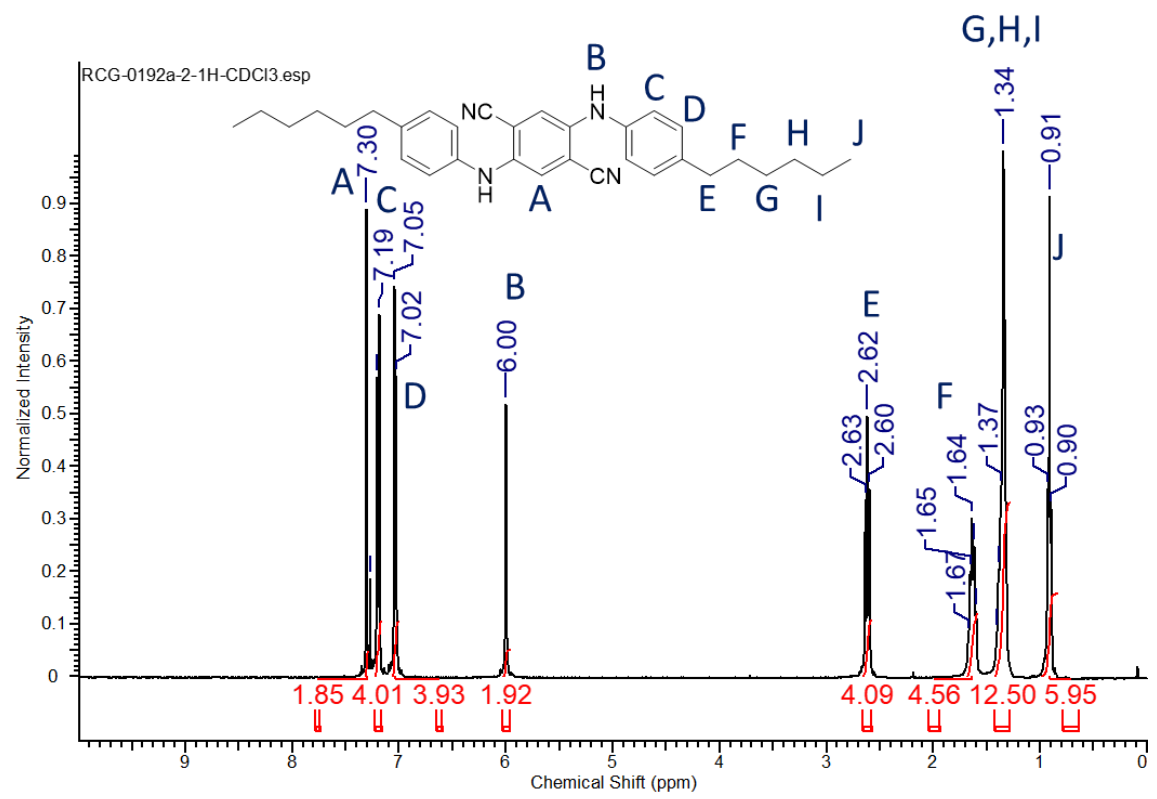

Figure S7. ${ }^{1} \mathrm{H}$ NMR spectrum (400 $\left.\mathrm{MHz}, \mathrm{CDCl}_{3}-d\right)$ of $\mathbf{3 a}$.

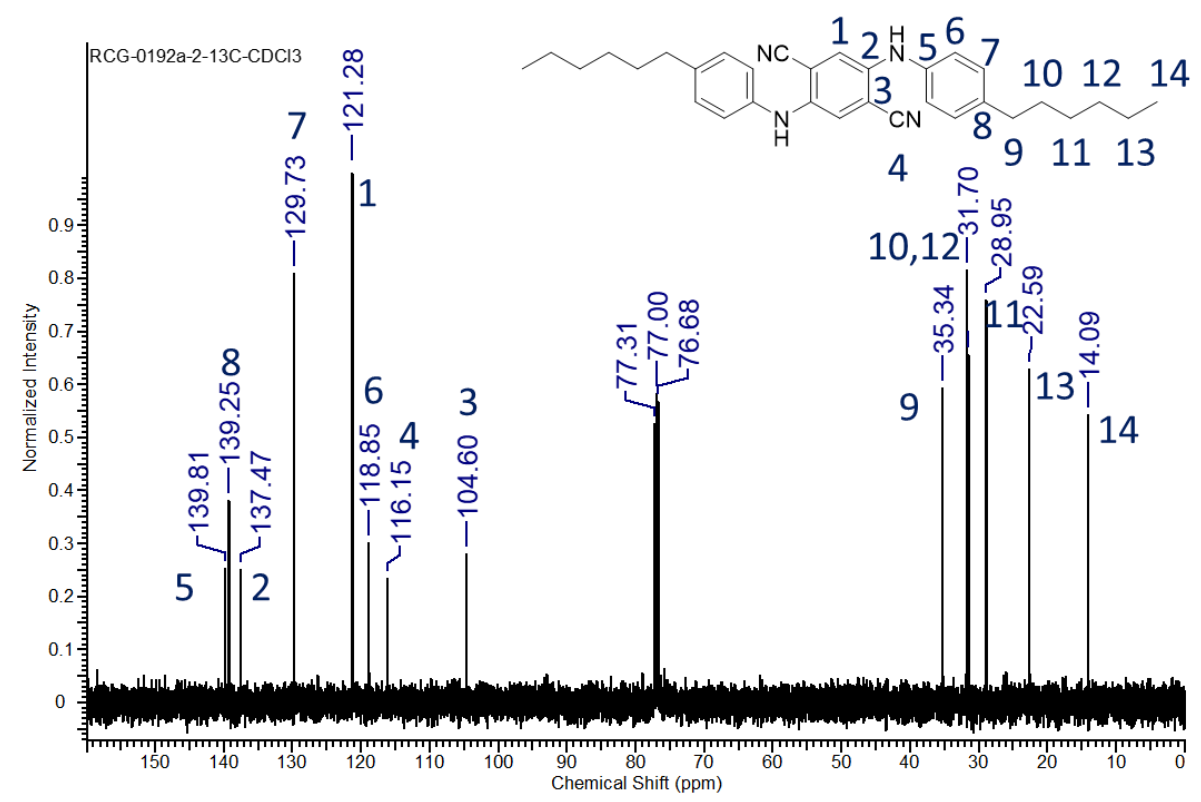

Figure S8. ${ }^{13} \mathrm{C}\{\mathrm{H}\} \mathrm{NMR}$ spectrum $\left(100 \mathrm{MHz}, \mathrm{CDCl}_{3}-d\right)$ of $\mathbf{3 a}$. 


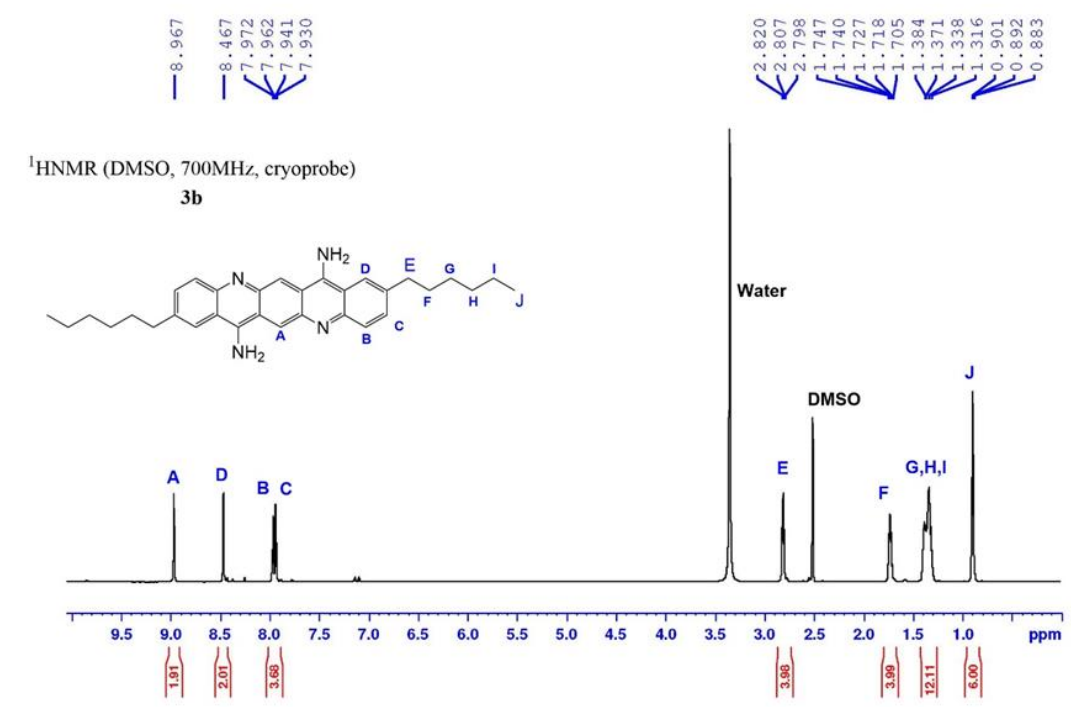

Figure S9. ${ }^{1} \mathrm{H}$ NMR spectrum (700 $\left.\mathrm{MHz}, \mathrm{DMSO}-d_{6}\right)$ of $\mathbf{3 b}$.
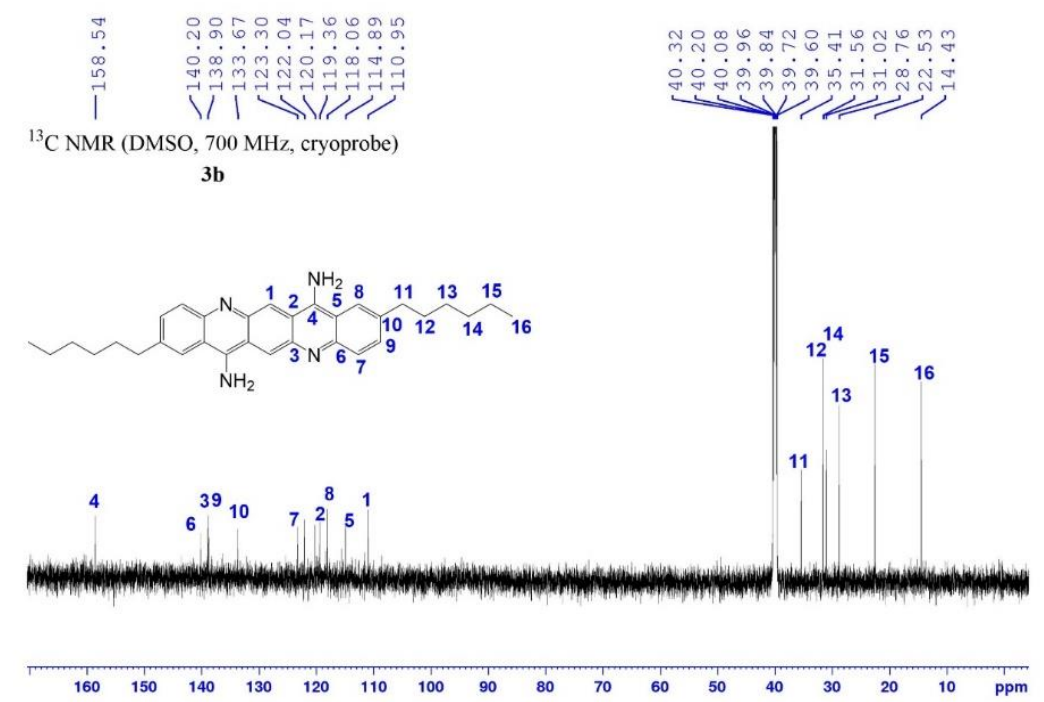

Figure S10. ${ }^{13} \mathrm{C}\{\mathrm{H}\}$ NMR spectrum $\left(176 \mathrm{MHz}, \mathrm{DMSO}-d_{6}\right)$ of $\mathbf{3 b}$. 


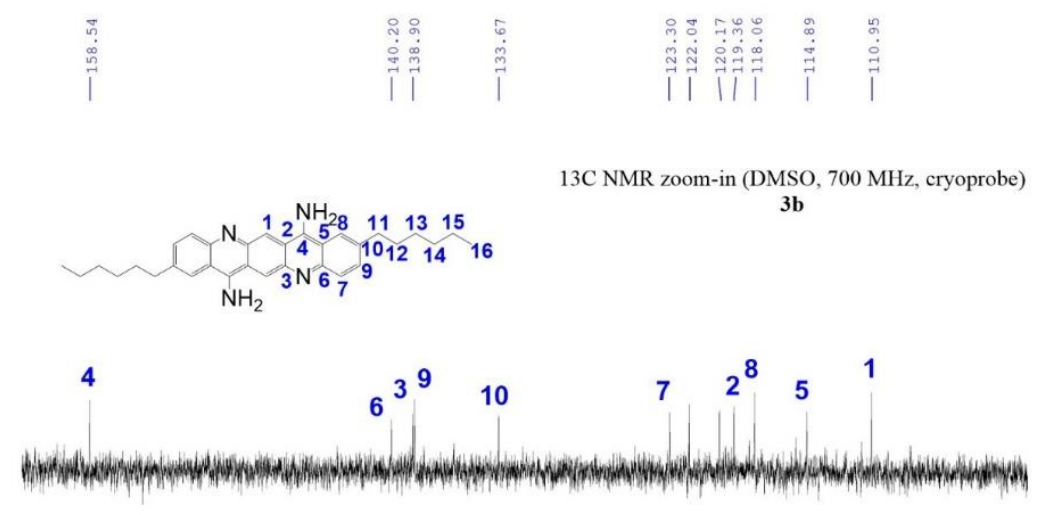

\begin{tabular}{|c|c|c|c|c|c|c|c|c|c|c|c|}
\hline 160 & 155 & 150 & 145 & 140 & 135 & 130 & 125 & 120 & 115 & 110 & $105 \mathrm{ppm}$ \\
\hline
\end{tabular}

Figure S11. ${ }^{13} \mathrm{C}\{\mathrm{H}\}$ NMR spectrum zoomed in aromatic region $\left(176 \mathrm{MHz}, \mathrm{DMSO}-d_{6}\right)$ of $\mathbf{3 b}$.

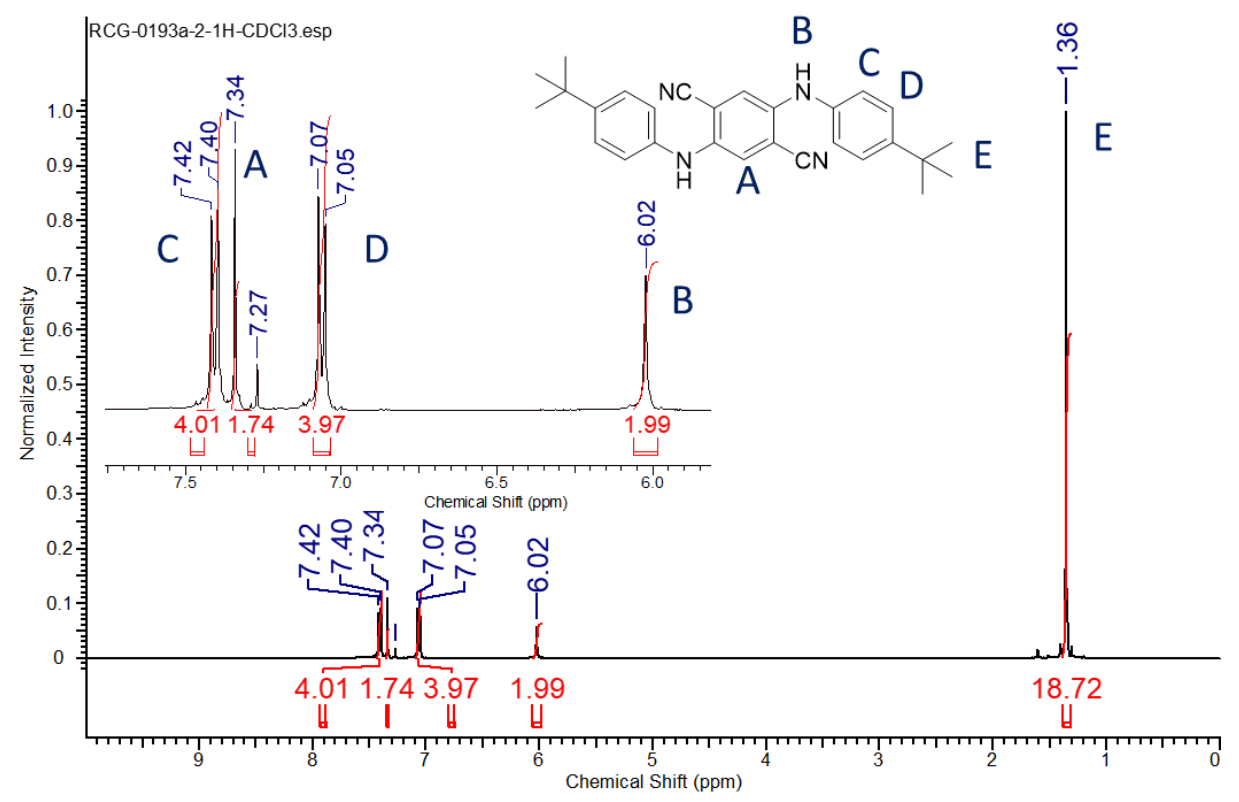

Figure S12. ${ }^{1} \mathrm{H} N M R$ spectrum $\left(400 \mathrm{MHz}, \mathrm{CDCl}_{3}-d\right)$ of $\mathbf{4 a}$. 


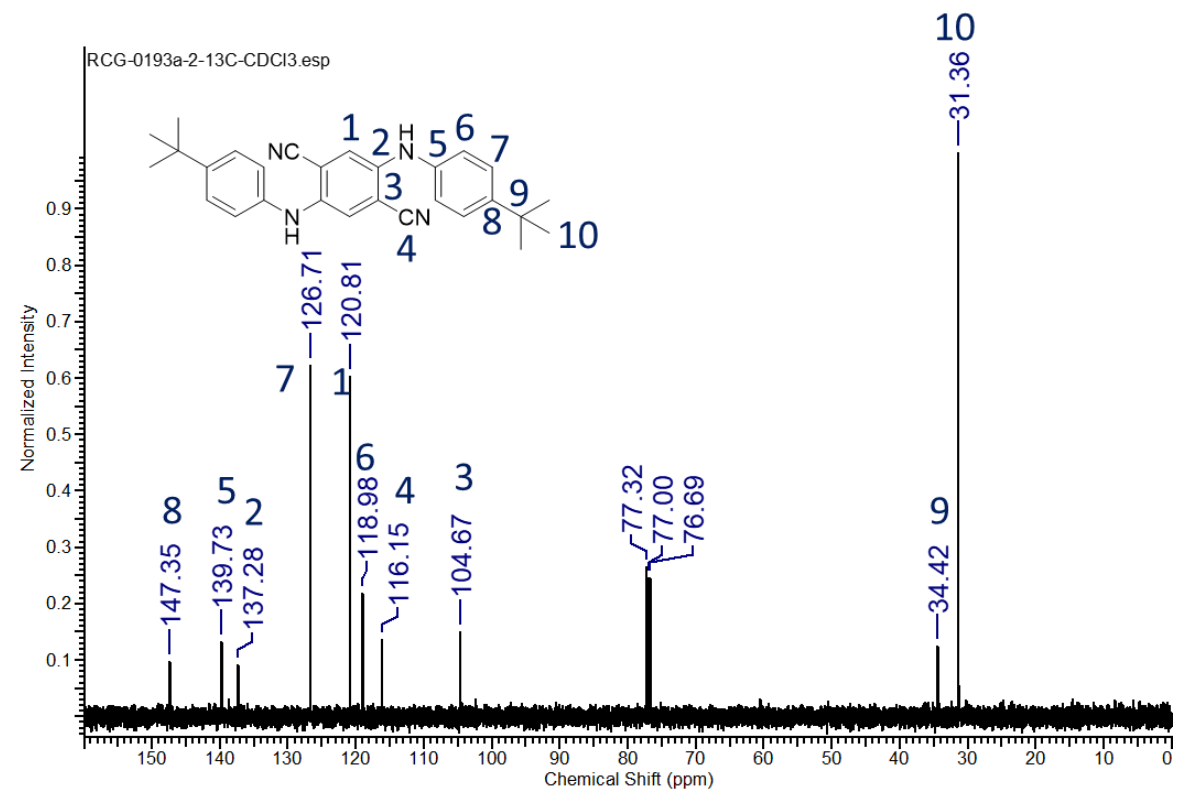

Figure S13. ${ }^{13} \mathrm{C}\{\mathrm{H}\} \mathrm{NMR}$ spectrum $\left(100 \mathrm{MHz}, \mathrm{CDCl}_{3}-d\right)$ of $\mathbf{4 a}$.

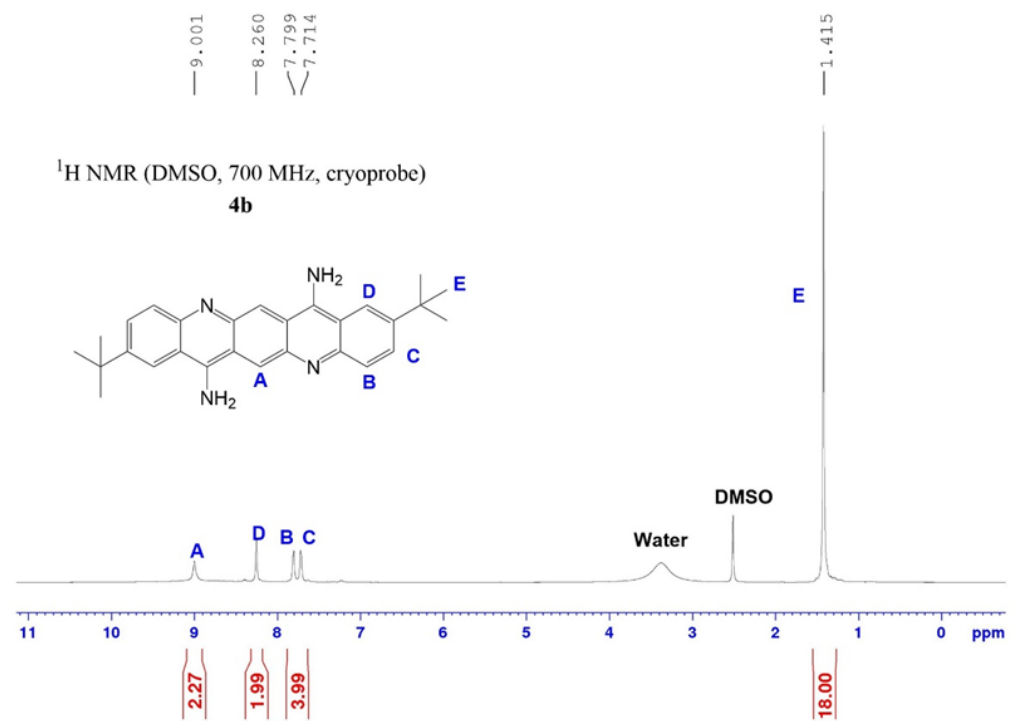

Figure S14. ${ }^{1} \mathrm{H}$ NMR spectrum (700 MHz, DMSO-d $)$ of $\mathbf{4 b}$. 


\section{|}

${ }^{13} \mathrm{C}$ NMR (DMSO, $700 \mathrm{MHz}$, cryoprobe)

4b
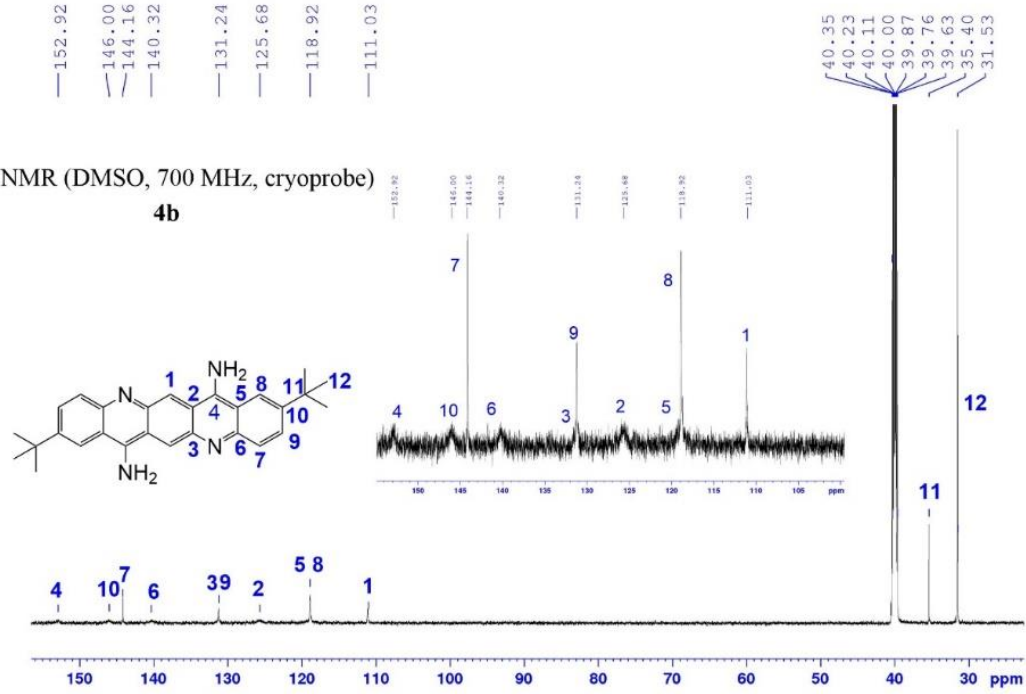

Figure S15. ${ }^{13} \mathrm{C}\{\mathrm{H}\}$ NMR spectrum $\left(176 \mathrm{MHz}, \mathrm{DMSO}-d_{6}\right)$ of $\mathbf{4 b}$.

\section{UV-VISIBLE SPECTROSCOPY}

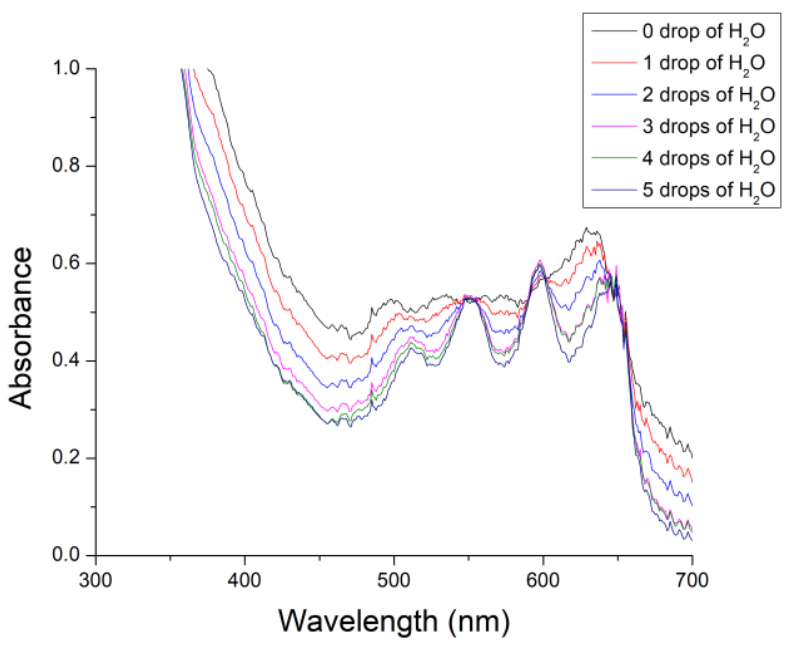

Figure S16. UV-Visible absorption spectra of $2 \boldsymbol{b}\left(1.5 \times 10^{-4} \mathrm{M}\right)$ in THF with the addition of $\mathrm{H}_{2} \mathrm{O}$. 
a.)

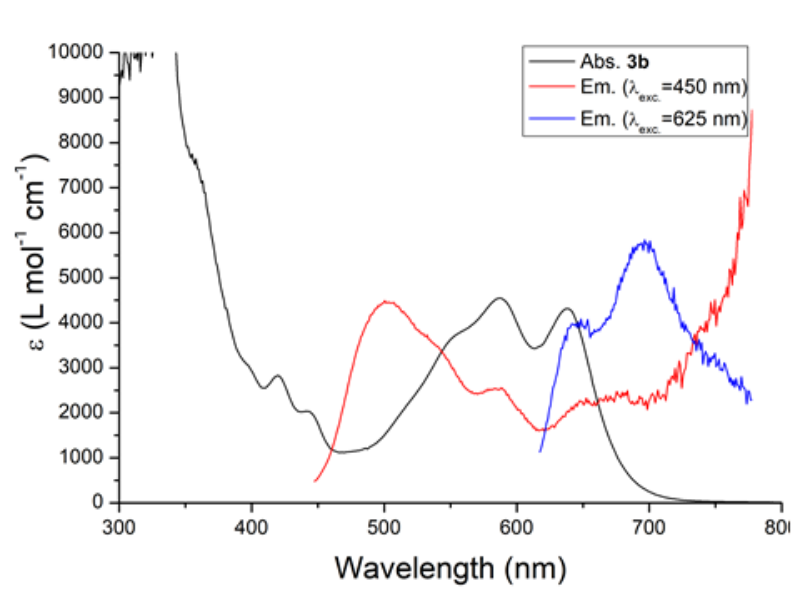

b.)

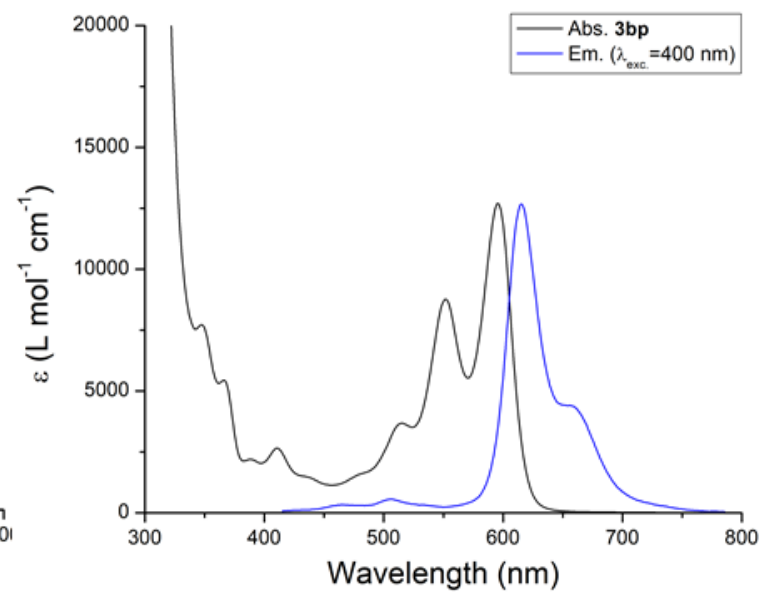

Figure S17. UV-Visible absorption and emission spectra of (a) $\mathbf{3 b}$ and (b) $\mathbf{3 b p}$.

a.)

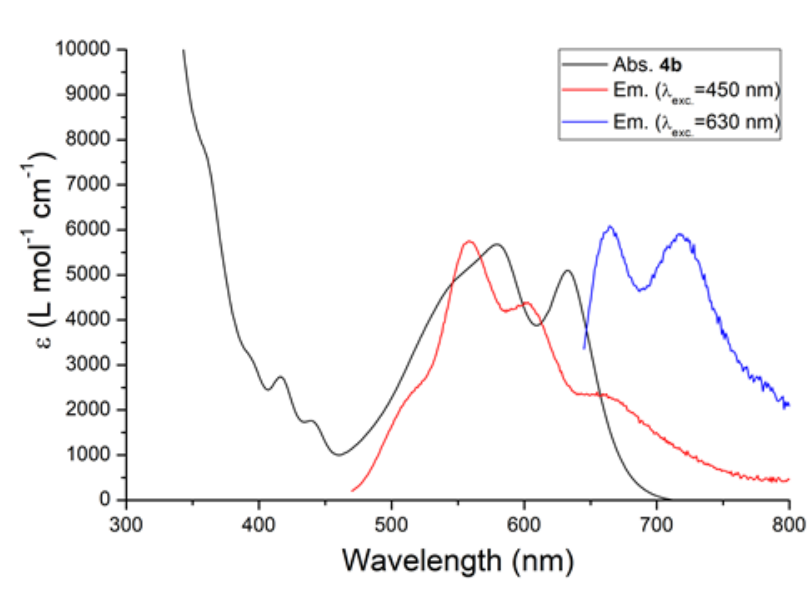

b.)

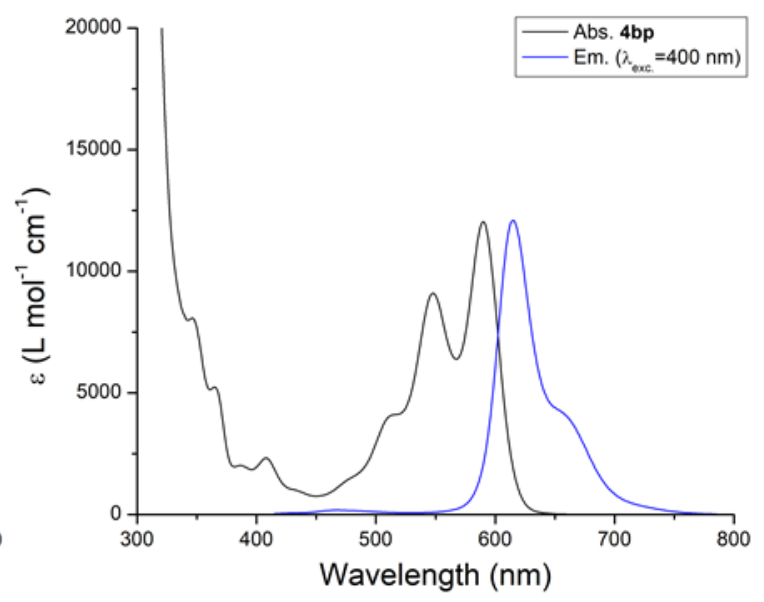

Figure S18. UV-Visible absorption and emission spectra of (a) $\mathbf{4 b}$ and (b) $\mathbf{4 b p}$. 
a.)

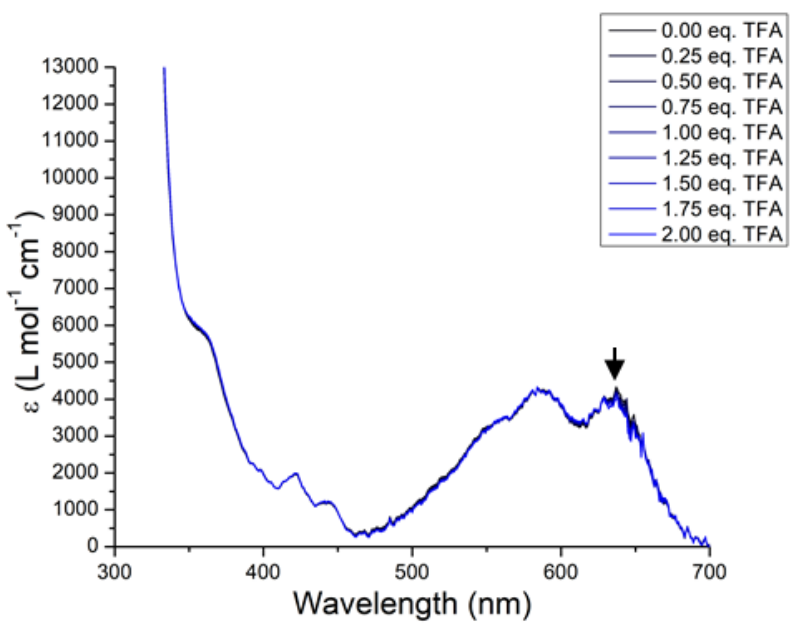

b.)

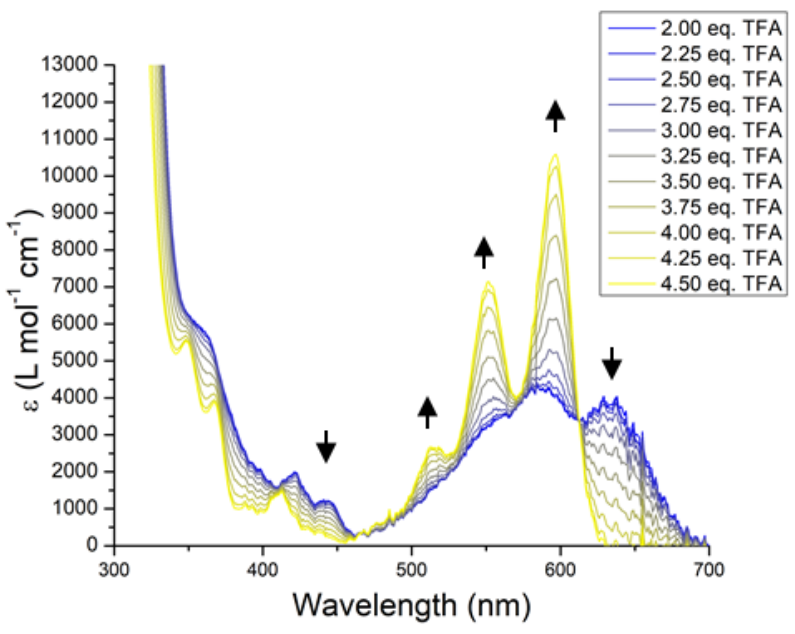

Figure S19. Acidochromism of $\mathbf{3 b}($ a) upon addition of 0.0-2.0 equivalents of TFA and $(b)$ upon addition of 2.0-4.5 equivalents of TFA in methanol.

a.)

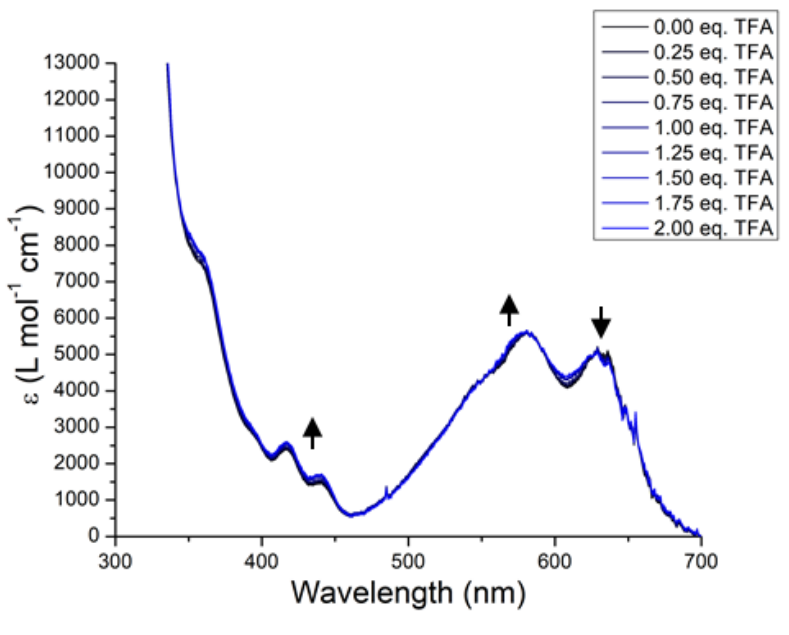

b.)

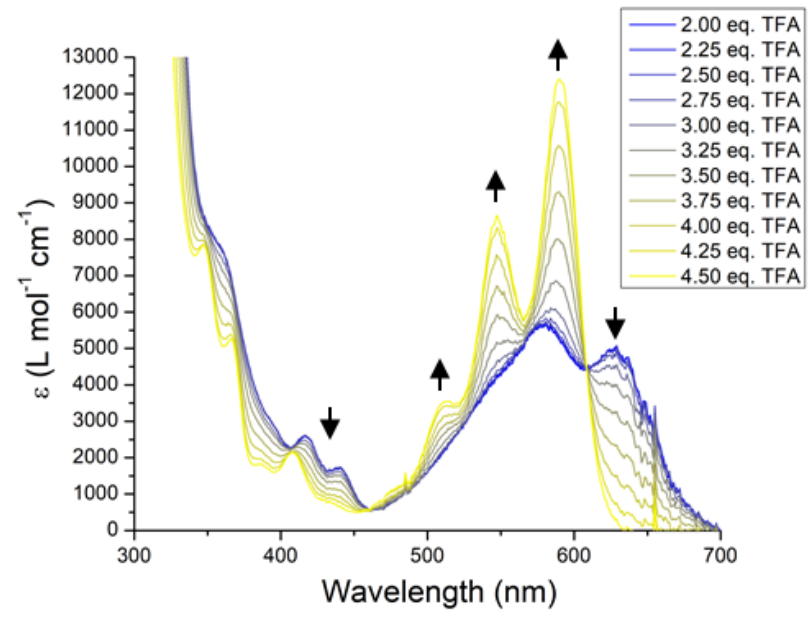

Figure S20. Acidochromism of $\mathbf{4 b}(a)$ upon addition of 0.0-2.0 equivalents of TFA and $(b)$ upon addition of 2.0-4.5 equivalents of TFA in methanol. 
a.)

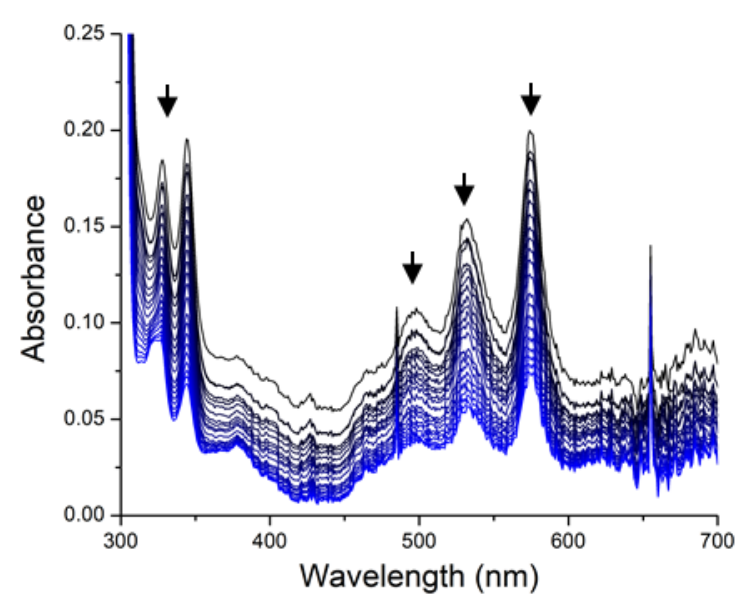

b.)

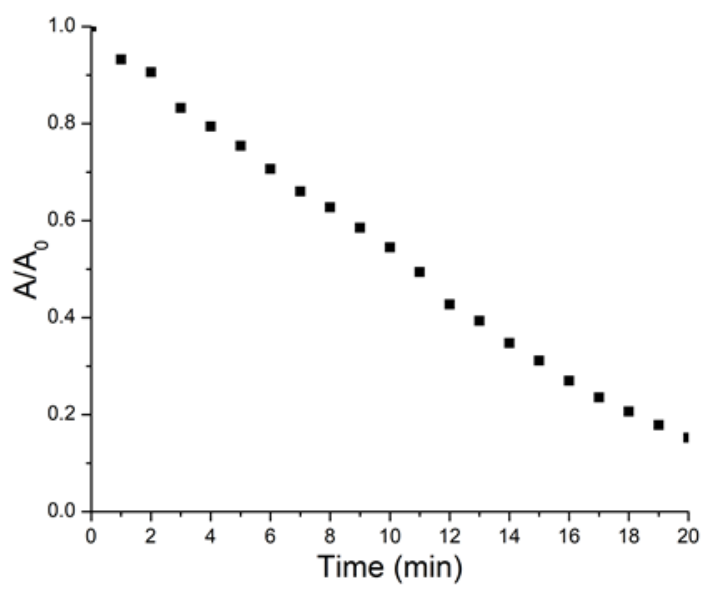

Figure S21. (a) The absorption spectra and (b) A/Ao vs. time plot for the degradation of $1.5 \times 10^{-4} \mathrm{M}$ pentacene in THF. 


\section{MASS SPECTROMETRY}

a.)

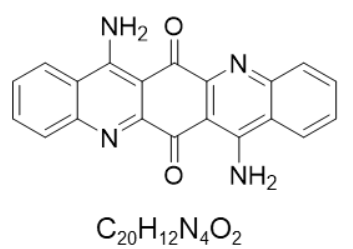

b.)

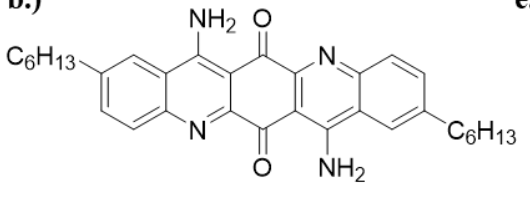

$\mathrm{C}_{32} \mathrm{H}_{36} \mathrm{~N}_{4} \mathrm{O}_{2}$

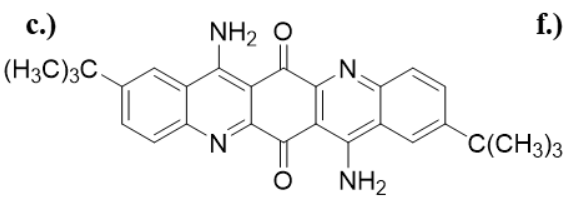

$\mathrm{C}_{28} \mathrm{H}_{28} \mathrm{~N}_{4} \mathrm{O}_{2}$

e.)

f.) d.)
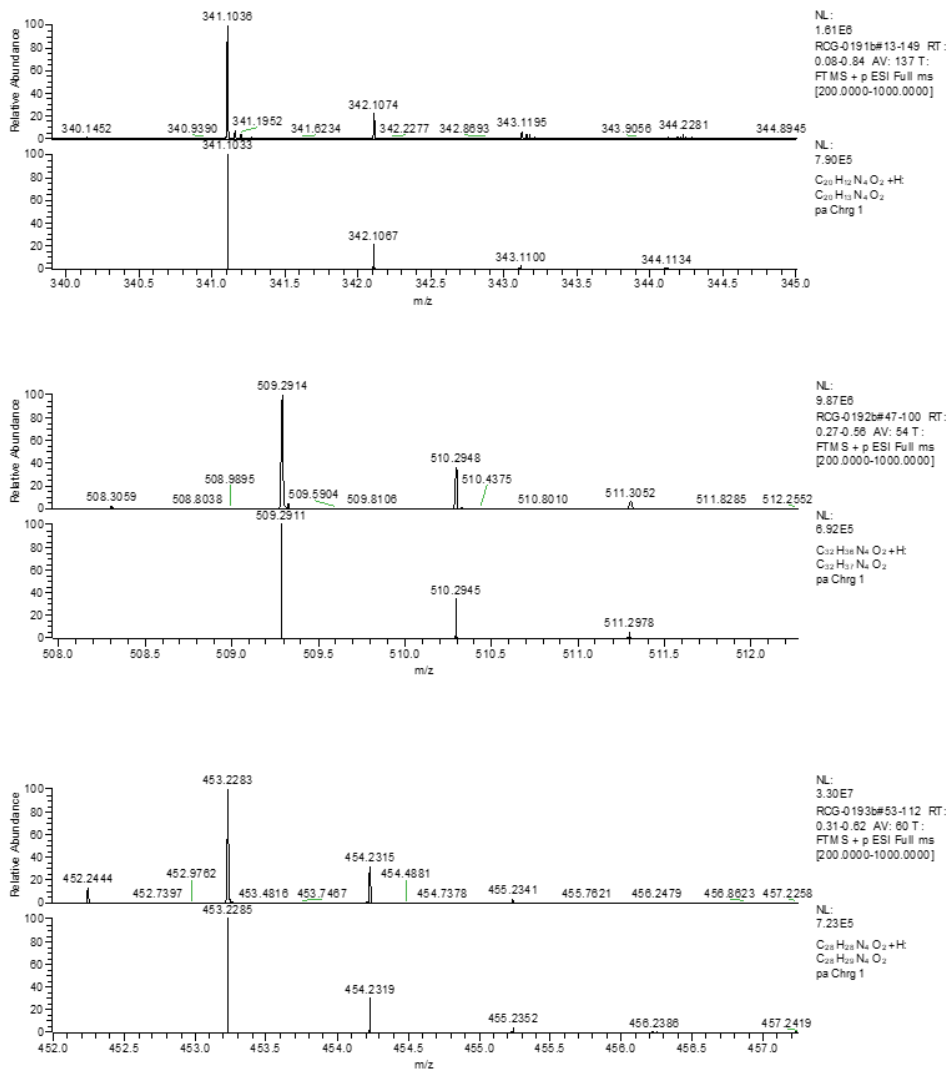

Figure S22. (a-c) The structures and molecular formulas of the oxidized $N$-heteropentacenes $\mathbf{2 b}$, $3 \boldsymbol{b}$, and $\mathbf{4 b}$ and $(d-f)$ their mass spectra. 
<smiles>Nc1c2ccccc2nc2cc3c(N)c4ccccc4nc3cc12</smiles><smiles>Nc1c2c(nc3ccccc13)C(=O)c1c(nc3ccccc3c1N)C2=O</smiles>

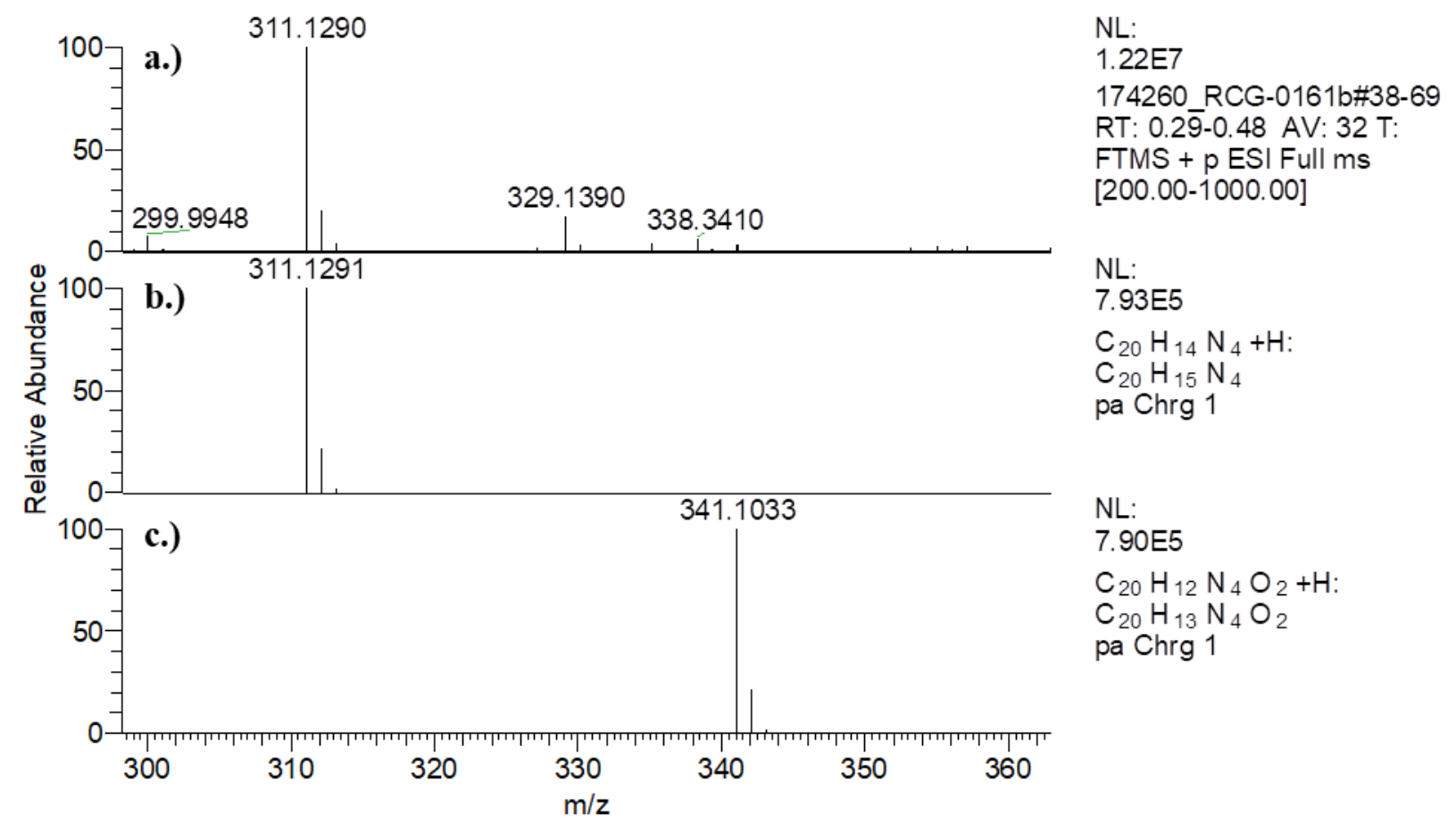

Figure S23. HRMS of $\mathbf{2 b}(a)$ experimental spectrum, (b) theoretical spectrum, and $(c)$ theoretical spectrum for oxidized $\mathbf{2 b}$. 


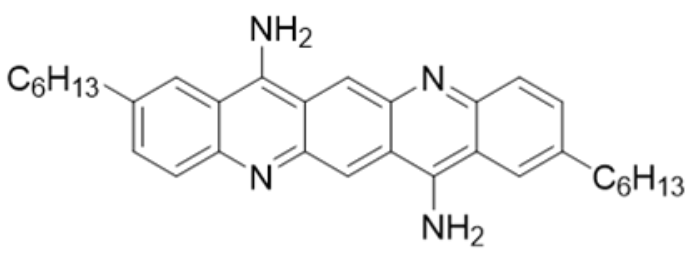

$\mathrm{C}_{32} \mathrm{H}_{38} \mathrm{~N}_{4}$

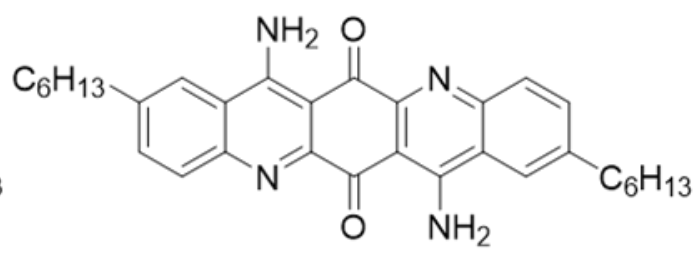

$\mathrm{C}_{32} \mathrm{H}_{36} \mathrm{~N}_{4} \mathrm{O}_{2}$

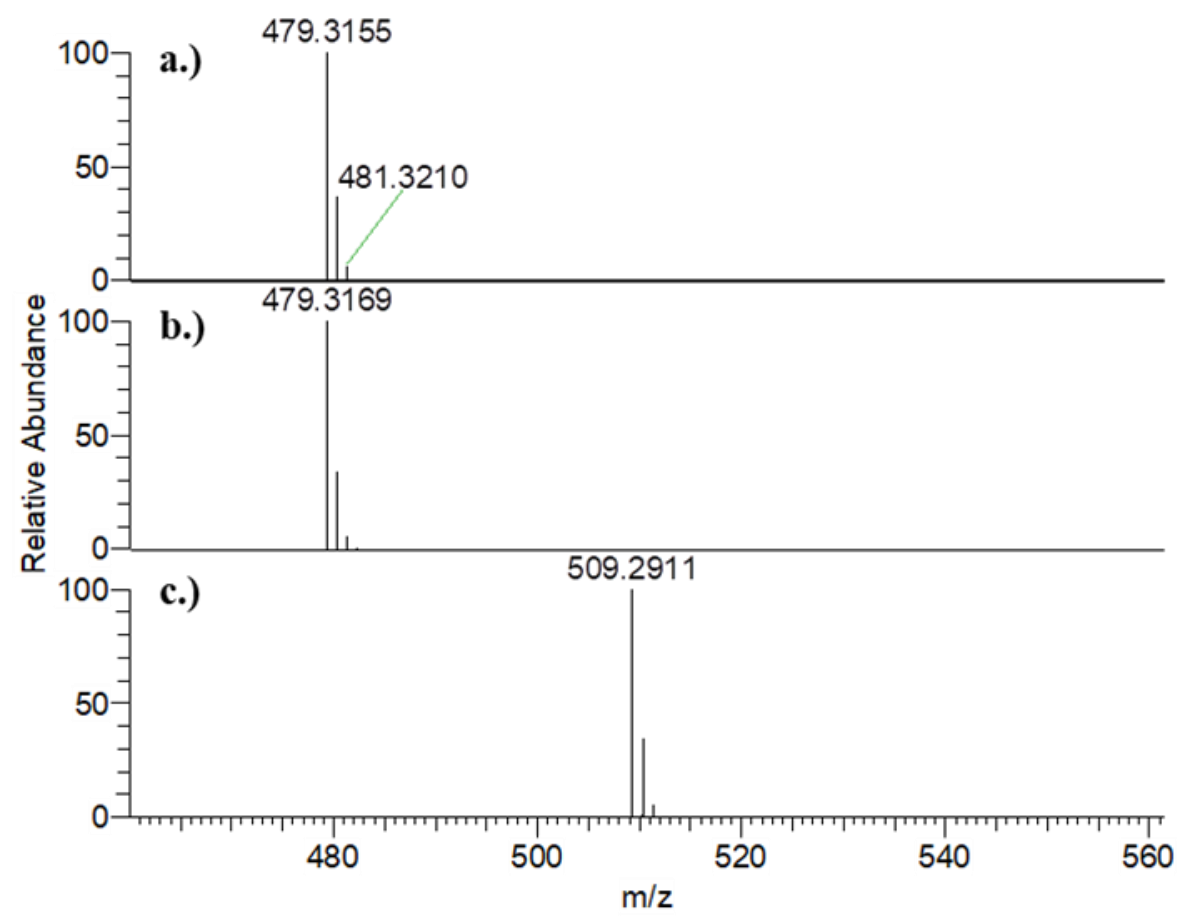

$\mathrm{NL}:$

6.39E8

174258 RCG-0163b\#53-69

RT: 0.37-0.45 AV: $17 \mathrm{~T}$ :

FTMS + p ESI Full ms

[200.00-1000.00]

NL:

6.95E5

$\mathrm{C}_{32} \mathrm{H}_{38} \mathrm{~N}_{4}+\mathrm{H}$ :

$\mathrm{C}_{32} \mathrm{H}_{39} \mathrm{~N}_{4}$

pa Chrg 1

NL:

6.92E5

$\mathrm{C}_{32} \mathrm{H}_{36} \mathrm{~N}_{4} \mathrm{O}_{2}+\mathrm{H}$ :

$\mathrm{C}_{32} \mathrm{H}_{37} \mathrm{~N}_{4} \mathrm{O}_{2}$

pa Chrg 1

Figure S24. HRMS of $\mathbf{3 b}($ a) experimental spectrum, (b) theoretical spectrum, and (c) theoretical spectrum for oxidized $\mathbf{3 b}$. 

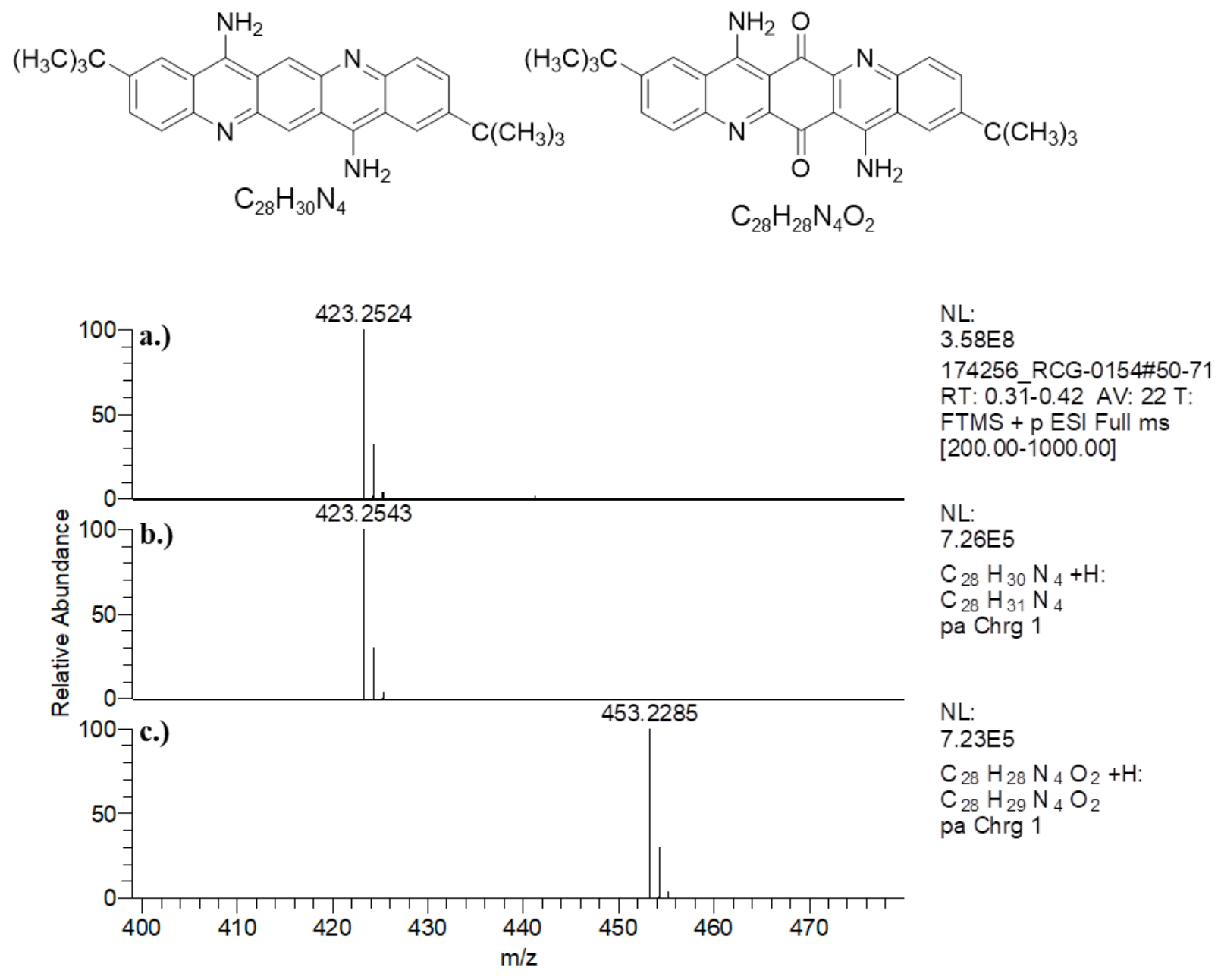

Figure $\mathbf{S 2 5}$. HRMS of $\mathbf{4 b}$ (top), theoretical MS for $\mathbf{4 b}$ (middle), and theoretical MS for oxidized $4 \boldsymbol{b}$ (bottom). 


\section{X-RAY CRYSTALLOGRAPHY}

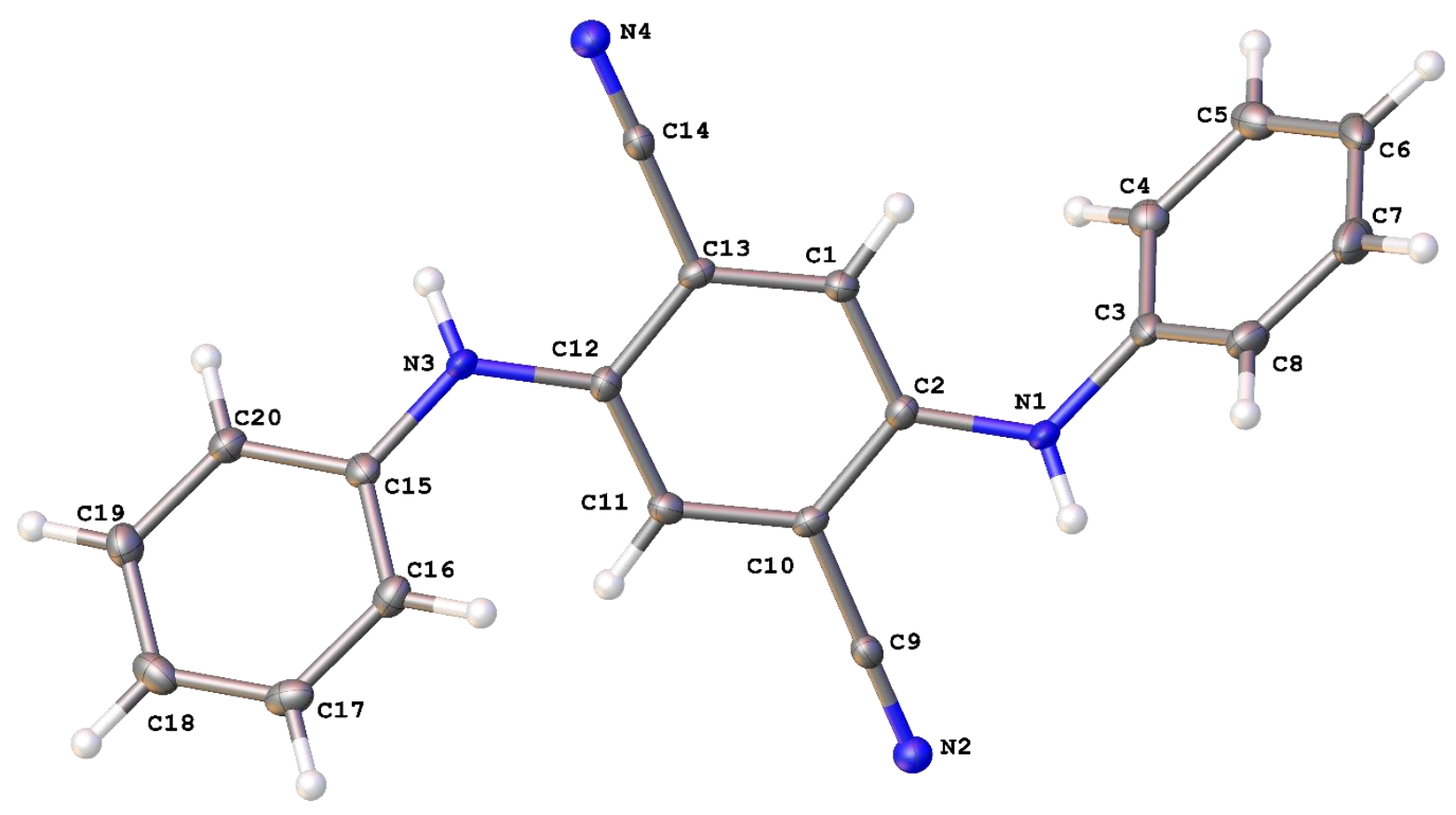

Figure S26. Thermal ellipsoid ${ }^{1}$ plot of compound 2a. Ellipsoids are drawn at $50 \%$ probability. Labels excluded for hydrogen atoms. Crystals were obtained from the slow evaporation of $15 \mathrm{mg}$ of $2 \mathrm{a}$ in $2 \mathrm{~mL}$ of acetone. 


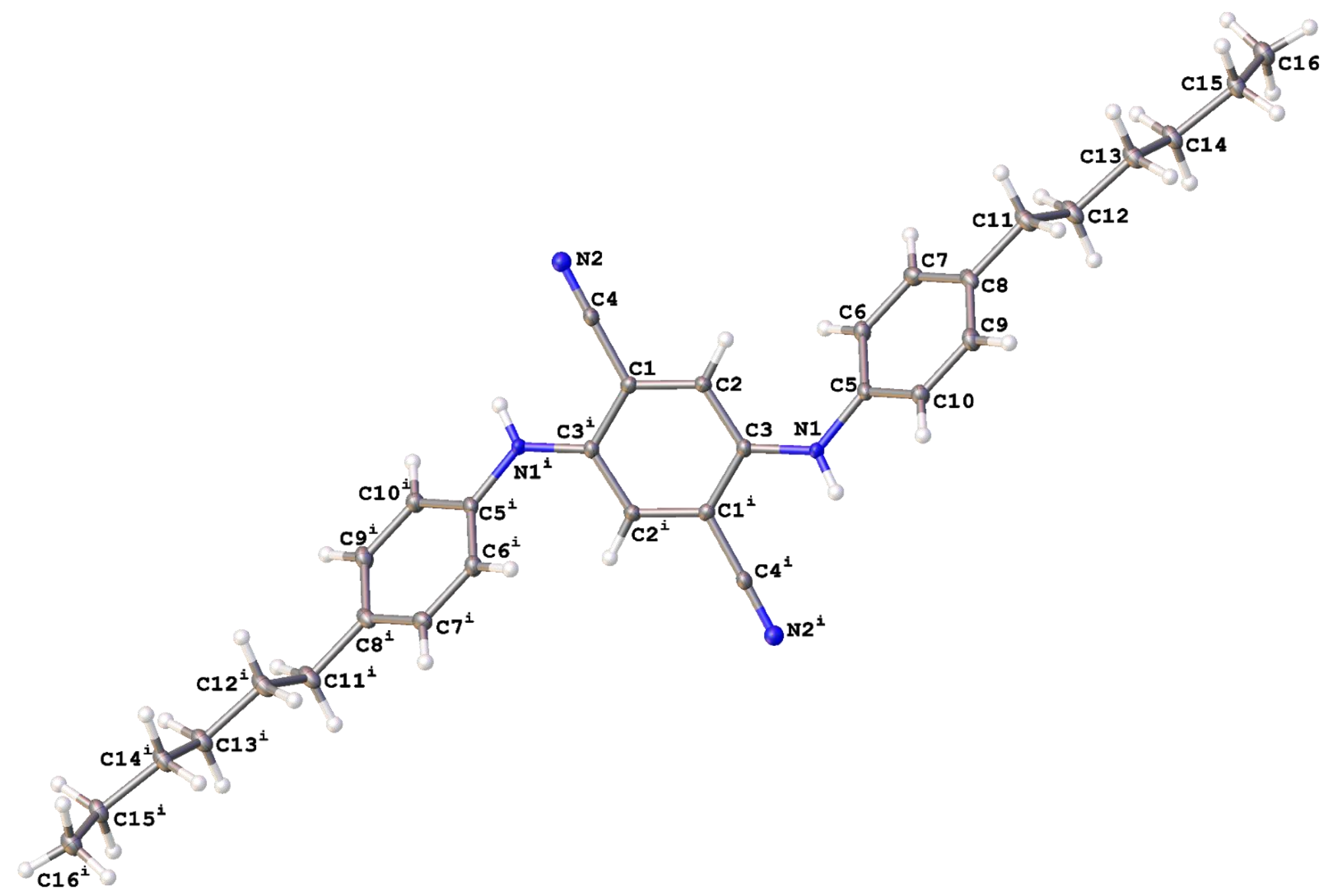

Figure S27. Thermal ellipsoid ${ }^{1}$ plot of compound 3a. Ellipsoids are drawn at 50\% probability. Symmetry equivalent atoms $(i=2-x$, 2$y, 2-z)$. Labels excluded for hydrogen atoms. Crystals were obtained from the slow evaporation of $8 \mathrm{mg}$ of $3 \mathrm{a}$ in $1.5 \mathrm{~mL}$ of acetone. 


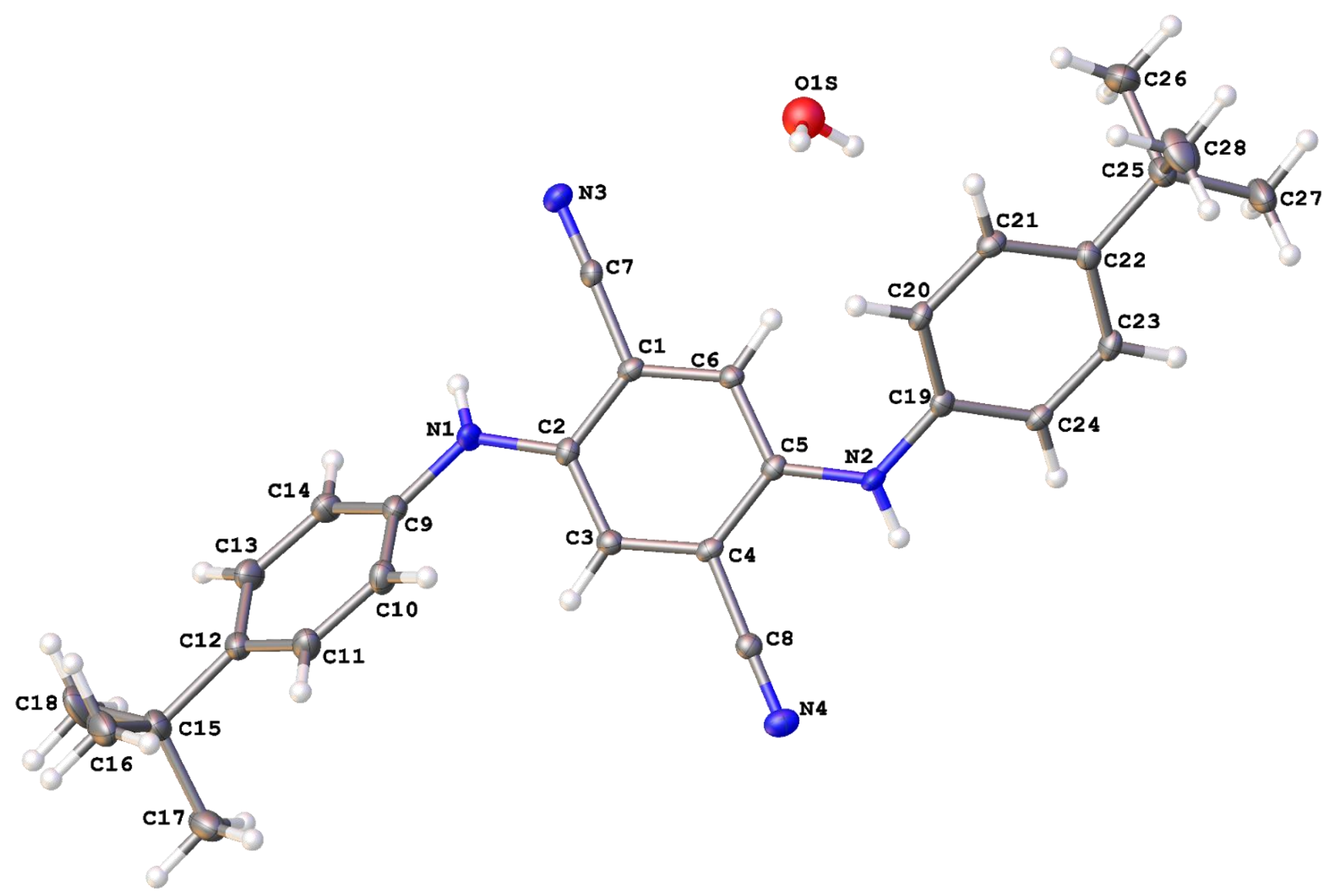

Figure S28. Thermal ellipsoid ${ }^{1}$ plot of compound 4a. Ellipsoids are drawn at 50\% probability. Solvent water is only $14 \%$ occupied. Labels excluded for hydrogen atoms. Crystals were obtained from the slow evaporation of $10 \mathrm{mg}$ of $4 \mathrm{a}$ in $1.5 \mathrm{~mL}$ of acetone. 


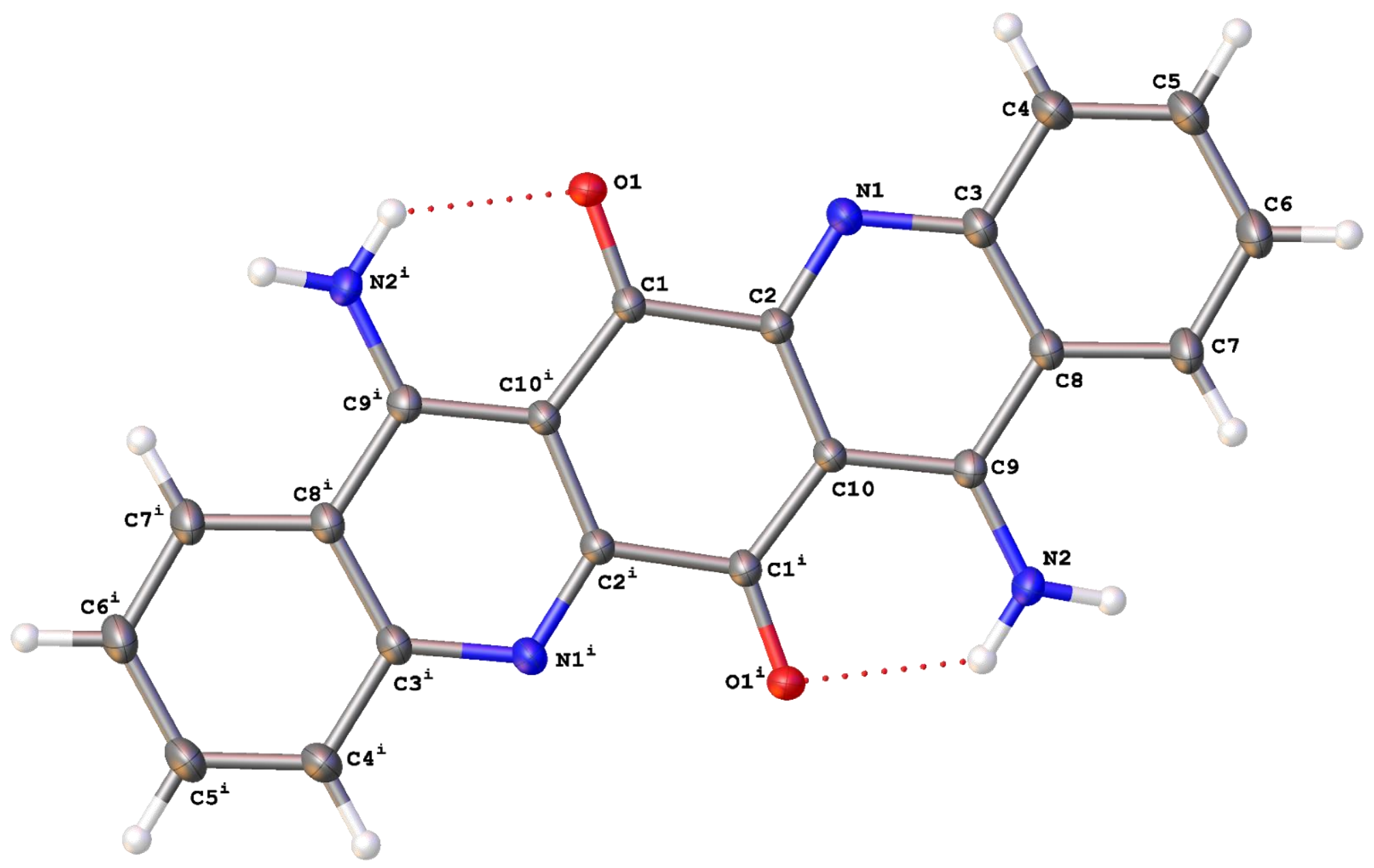

Figure S29. Thermal ellipsoid ${ }^{1}$ plot of oxidized compound 2b. Ellipsoids are drawn at 50\% probability. Symmetry notations: $i=1-x$, $1-y,-z$. Disordered DMSO solvent excluded from image. Labels excluded for hydrogen atoms. Crystals were obtained from the slow evaporation of $10 \mathrm{mg}$ of $\mathbf{2 b}$ in $2 \mathrm{~mL}$ of DMSO. The solution was kept in the dark. 


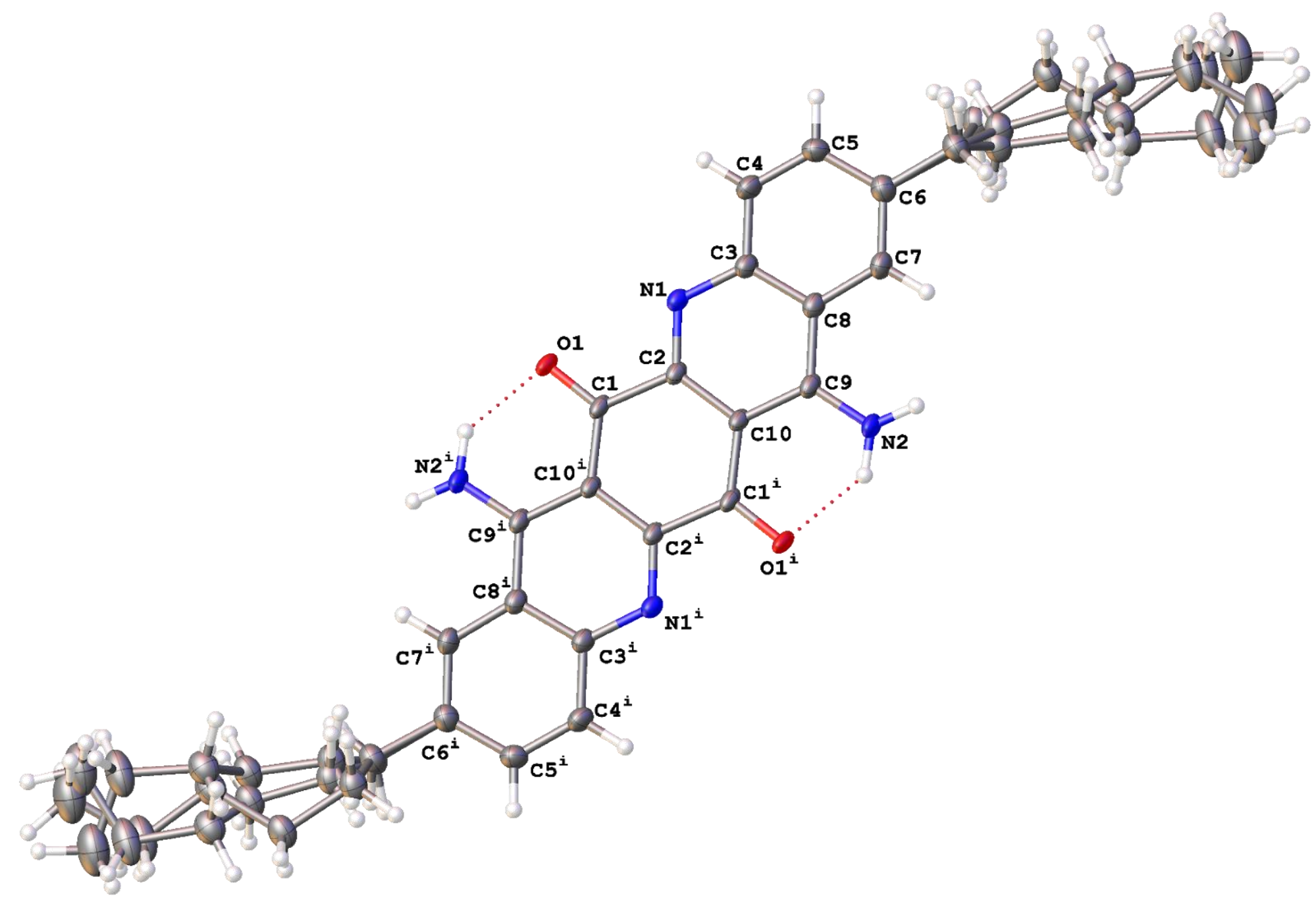

Figure S30. Thermal ellipsoid ${ }^{1}$ plot of oxidized compound 3 b. Ellipsoids are drawn at 50\% probability. Labels excluded for disordered atoms and hydrogen atoms. Symmetry notations: $i=1-x, 2-y, 1-z$. All three orientations of disordered alkyl chain are shown. Crystals were obtained from the slow evaporation of $10 \mathrm{mg}$ of $3 \boldsymbol{b}$ in $2 \mathrm{~mL}$ of DMSO. The solution was kept in the dark. 
Table S1. X-ray crystallography data of the precursors.

\begin{tabular}{|c|c|c|c|}
\hline Precursor & $2 \mathrm{a}$ & $3 a$ & $4 \mathrm{a}$ \\
\hline $\begin{array}{l}\text { Identification } \\
\text { code }\end{array}$ & rds772 & $\operatorname{rds} 757$ & rds756 \\
\hline $\begin{array}{l}\text { Chemical } \\
\text { formula }\end{array}$ & $\mathrm{C}_{20} \mathrm{H}_{14} \mathrm{~N}_{4}$ & $\mathrm{C}_{32} \mathrm{H}_{38} \mathrm{~N}_{4}$ & $\mathrm{C}_{28} \mathrm{H}_{30.28} \mathrm{~N}_{4} \mathrm{O}_{0.14}{ }^{*}$ \\
\hline Formula weight & $310.35 \mathrm{~g} / \mathrm{mol}$ & $478.66 \mathrm{~g} / \mathrm{mol}$ & $425.09 \mathrm{~g} / \mathrm{mol}$ \\
\hline Temperature & $100(2) \mathrm{K}$ & $100(2) \mathrm{K}$ & $100(2) \mathrm{K}$ \\
\hline Wavelength & $0.71073 \AA$ & $0.71073 \AA$ & $0.71073 \AA$ \\
\hline Crystal size & $\begin{array}{l}0.085 \times 0.104 \times \\
0.219 \mathrm{~mm}\end{array}$ & $\begin{array}{l}0.055 \times 0.084 \times \\
0.253 \mathrm{~mm}\end{array}$ & $\begin{array}{l}0.130 \times 0.138 \times \\
0.247 \mathrm{~mm}\end{array}$ \\
\hline Crystal habit & orange rod & orange needle & orange block \\
\hline Crystal system & monoclinic & triclinic & monoclinic \\
\hline Space group & P $121 / n 1$ & $\mathrm{P}-1$ & P 1 21/n 1 \\
\hline \multirow{6}{*}{$\begin{array}{l}\text { Unit cell } \\
\text { dimensions }\end{array}$} & $\mathrm{a}=10.4305(7) \AA$ & $a=4.6765(2) \AA$ & $\mathrm{a}=21.0773(14) \AA$ \\
\hline & $\mathrm{b}=8.8050(6) \AA$ & $\mathrm{b}=8.8636(4) \AA$ & $\mathrm{b}=6.9231(5) \AA$ \\
\hline & $\mathrm{c}=17.1263(11) \AA$ & $\mathrm{c}=16.2126(8) \AA$ & $\mathrm{c}=16.9633(11) \AA$ \\
\hline & $\alpha=90^{\circ}$ & $\alpha=94.8546(18)^{\circ}$ & $\alpha=90^{\circ}$ \\
\hline & $\beta=100.262(2)^{\circ}$ & $\beta=96.9690(18)^{\circ}$ & $\beta=101.741(2)^{\circ}$ \\
\hline & $\gamma=90^{\circ}$ & $\gamma=97.109(2)^{\circ}$ & $\gamma=90^{\circ}$ \\
\hline Volume & $1547.73(18) \AA^{3}$ & $658.53(5) \AA^{3}$ & $2423.5(3) \AA^{3}$ \\
\hline $\mathbf{Z}$ & 4 & 1 & 4 \\
\hline $\begin{array}{l}\text { Density } \\
\text { (calculated) }\end{array}$ & $1.332 \mathrm{~g} / \mathrm{cm}^{3}$ & $1.207 \mathrm{~g} / \mathrm{cm}^{3}$ & $1.165 \mathrm{~g} / \mathrm{cm}^{3}$ \\
\hline $\begin{array}{l}\text { Absorption } \\
\text { coefficient }\end{array}$ & $0.082 \mathrm{~mm}^{-1}$ & $0.071 \mathrm{~mm}^{-1}$ & $0.070 \mathrm{~mm}^{-1}$ \\
\hline$F(000)$ & 648 & 258 & 910 \\
\hline
\end{tabular}

"Note that the chemical formula is off due to the presence of water in the unit cell. 
Table S2. X-ray crystallography data of the oxidized diazapentacenes.

\begin{tabular}{|c|c|c|}
\hline Precursor & $2 \mathrm{~b}$ (oxidized) & 3b (oxidized) \\
\hline $\begin{array}{l}\text { Identification } \\
\text { code }\end{array}$ & rds794 & rds793 \\
\hline $\begin{array}{l}\text { Chemical } \\
\text { formula }\end{array}$ & $\mathrm{C}_{20.67} \mathrm{H}_{14} \mathrm{~N}_{4} \mathrm{O}_{2.33} \mathrm{~S}_{0.33}{ }^{*}$ & $\mathrm{C}_{32} \mathrm{H}_{36} \mathrm{~N}_{4} \mathrm{O}_{2}$ \\
\hline Formula weight & $366.38 \mathrm{~g} / \mathrm{mol}$ & $508.65 \mathrm{~g} / \mathrm{mol}$ \\
\hline Temperature & $100(2) \mathrm{K}$ & $100(2) \mathrm{K}$ \\
\hline Wavelength & $0.71073 \AA$ & $0.71073 \AA$ \\
\hline Crystal size & $0.106 \times 0.111 \times 0.240 \mathrm{~mm}$ & $0.046 \times 0.268 \times 0.429 \mathrm{~mm}$ \\
\hline Crystal habit & orange rod & orange plate \\
\hline Crystal system & trigonal & monoclinic \\
\hline Space group & $\mathrm{R}-3$ & P $121 / \mathrm{c} 1$ \\
\hline \multirow{6}{*}{$\begin{array}{l}\text { Unit cell } \\
\text { dimensions }\end{array}$} & $\mathrm{a}=26.0163(18) \AA$ & $\mathrm{a}=10.4169(5) \AA$ \\
\hline & $\mathrm{b}=26.0163(18) \AA$ & $\mathrm{b}=9.4055(5) \AA$ \\
\hline & $\mathrm{c}=6.8761(5) \AA$ & $\mathrm{c}=14.6021(8) \AA$ \\
\hline & $\alpha=90^{\circ}$ & $\alpha=90^{\circ}$ \\
\hline & $\beta=90^{\circ}$ & $\beta=109.1784(17)^{\circ}$ \\
\hline & $\gamma=120^{\circ}$ & $\gamma=90^{\circ}$ \\
\hline Volume & $4030.5(6) \AA^{3}$ & $1351.26(12) \AA^{3}$ \\
\hline $\mathbf{Z}$ & 9 & 2 \\
\hline $\begin{array}{l}\text { Density } \\
\text { (calculated) }\end{array}$ & $1.358 \mathrm{~g} / \mathrm{cm}^{3}$ & $1.250 \mathrm{~g} / \mathrm{cm}^{3}$ \\
\hline $\begin{array}{l}\text { Absorption } \\
\text { coefficient }\end{array}$ & $0.129 \mathrm{~mm}^{-1}$ & $0.079 \mathrm{~mm}^{-1}$ \\
\hline $\mathbf{F ( 0 0 0 )}$ & 1710 & 544 \\
\hline
\end{tabular}

"Note that the chemical formula is off due to the presence of DMSO in the unit cell.

\section{REFERENCES}

(1) Dolomanov, O. V.; Bourhis, L. J.; Gildea, R. J.; Howard, J. A. K.; Puschmann, H. OLEX2: A Complete Structure Solution, Refinement and Analysis Program. J. Appl. Cryst. 2009, 42, 339341. 